Winter 2013

\title{
Globalization and the Privatization of Welfare Administration in Indiana
}

Alfred C. Aman

Indiana University Maurer School of Law, aaman@indiana.edu

Follow this and additional works at: https://www.repository.law.indiana.edu/ijgls

Part of the Social Welfare Law Commons

\section{Recommended Citation}

Aman, Alfred C. (2013) "Globalization and the Privatization of Welfare Administration in Indiana," Indiana Journal of Global Legal Studies: Vol. 20 : Iss. 1 , Article 13.

Available at: https://www.repository.law.indiana.edu/ijgls/vol20/iss1/13

This Symposium is brought to you for free and open access by the Law School Journals at Digital Repository @ Maurer Law. It has been accepted for inclusion in Indiana Journal of Global Legal Studies by an authorized editor of Digital Repository @ Maurer Law. For more information, please contact rvaughan@indiana.edu.

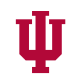

JEROME HALL LAW LIBRARY

INDIANA UNIVERSITY

Maurer School of Law
Blooming ton 


\title{
Globalization and the Privatization of Welfare Administration in Indiana
}

\author{
ALFRED C. AMAN, JR.*
}

\begin{abstract}
This article explores the relationship of globalization to domestic law in the context of privatized welfare services in Indiana. It examines the ways that privatization can affect vulnerable populations such as welfare recipients by, in effect, partially dis-embedding the market from the state. It applies Karl Polanyi's conception of a double movement to illustrate how the political process can, in effect, re-embed the market in the state. Utilizing Indiana's recent experiences with welfare administration privatization, this article shows that re-embedding is not a simple question of reversing decisions already taken, but rather a complex sequencing of political and legal engagements. It recommends law reforms aimed at more easily triggering the kinds of political actions anticipated by Polanyi's analysis.
\end{abstract}

\section{INTRODUCTION}

Understanding the relationship between globalization and law requires analysis of the interactions of markets and law at all levels, domestic and international, as well as diverse processes of norm creation, enforcement, and adjudication by state and nonstate actors alike. Complex sociopolitical interrelationships and interlegalities result from these interactions. Domestic law is one effect of globalization, and conversely, our conceptions of globalization are also (in part) effects of

* Roscoe C. O'Byrne Professor of Law, Indiana University Maurer School of Law-Bloomington. I would like to thank John Fleming, '12, and Kate McTavish, '13, for their excellent research during the early stages of this article. I would also like to thank Justin Olson, '13, for his excellent research assistance as the article neared completion and was prepared for publication.

Indiana Journal of Global Legal Studies Vol. 20, Issue 1 (2013)

CC Indiana University Maurer School of Law 
domestic law. ${ }^{1}$ This article will focus on these recursive effects through a case study involving the interplay of domestic law in relation to the denationalizing forces of globalization in the highly domestic context of social services.

Understanding the role of domestic law in the current global environment involves two main perspectives. The first is a domestic perspective on globalization, so as to appreciate the extent to which globalization is produced and experienced in highly diverse ways in different times, places, and circumstances. Taking a domestic perspective on globalization reminds us that globalization is neither uniform nor somehow "above" society and its institutions; it does not erase or mitigate the specificity of local contexts and concerns. Thus, globalization enlarges the scope for comparison at the same time that it requires us to take into account the specifics of localized differences, as these are also meaningful.

The second perspective is closely related to the first: understanding domestic law's role today also means taking a global perspective on domestic affairs. This goes beyond the interplay of the local and translocal just described. "Global forces" are not only or wholly the effects of extraterritorial or translocal (transnational) phenomena. They do not necessarily come from beyond national borders or beyond national governments. On the contrary, globalization is deeply embedded within domestic institutions and their participants-both public and private-as ideas, relations, interests, and effects. This situation poses both opportunities and constraints on the relevance of law and the potential for law reform, especially as affecting vulnerable populations. As we shall see, globalization is not just a top down affair.

\section{DOUbLe PERSPectives ON THE MARKETIZATION OF SOCIAL SERVICES}

To illustrate the importance of these perspectives to discussions of law reform, this article will focus primarily on the privatization of welfare administration through one "extended case" involving the state of Indiana. ${ }^{2}$ I chose this case because it illustrates so vividly both perspectives described above as well as the potential for law reform arising from what Karl Polanyi calls "the double movement" between

1. See Alfred C. Aman, JR., The Democracy Deficit: Taming Globalization THROUGH LAW REFORM 124-27 (2004).

2. See generally J. Van Velsen, The Extended-Case Method and Situational Analysis, in The CRAFT OF Social ANTHROPOLOGY 129-49 (A. L. Epstein ed., 1967) (explaining the use of the "extended case" method). 
the state and the market. ${ }^{3}$ In his classic book, The Great Transformation, Polanyi argues that the self-regulating market is a utopian myth that tends to normalize the dominance of market forces. ${ }^{4}$ To this we might add the observation that the myth of the self-regulating market tends to limit the political questions in marketization to the value of efficiency. This was the case for certain categories of vulnerable populations in the United States. The emphasis on costs and efficiency in the context of privatized welfare services, privatized prisons, and the administration of unregistered immigrants obviates, to a great degree, many of the political, social, and ethical issues that these social contexts might otherwise involve. ${ }^{5}$ This situation might, at least theoretically, in Polanyi's terms, trigger what he refers to as a "double movement"-a sharp political reaction in the form of new demands upon the state on behalf of those whose issues go beyond efficiency and cost; 6 however, in the United States, these groups have so little political power that their needs do not usually rise to the level of a public contest. Indeed, the existence of persistent poverty is often assumed to be a function of the global marketplace working normallyi.e. efficiently, with maximum reduction of fixed cost points. A marketbased model of globalization underlies these domestic reforms.

Polanyi anticipates that marketization would produce political conditions that would result in the reversal of the processes that (in his term) "dis-embed" the state from the market. ${ }^{7}$ The case this article explores shows that re-embedding the state is not a simple question of reversing decisions taken, but rather a complex sequencing of political and legal engagements. We shall return to Polanyi later in the discussion. ${ }^{8}$

As background to the case, I note that in the United States, the marketization of social services became politically popular as electorates became newly aware of global economic competition in the 1980 s and $1990 \mathrm{~s}$, resulting in a major transformation in both the idea of "the public" and the way the public sector functions in American life. 9

3. See Karl Polany, The Great Transformation: The Political and Economic ORIGINS OF OUR TIME 79-80 (2d ed., Beacon Press 2001) (1944).

4. See id. at 71 .

5. See AMAN, supra note 1, at 7. See also Sharon Dolovich, How Privatization Thinks: The Case of Prisons, in GOVERNMENT BY CONTRACT: OUTSOURCING AND AMERICAN DEMOCRACY 128-30 (Jody Freeman \& Martha Minow eds., 2009).

6. See POLANYI, supra note 3 , at 79-80.

7. Id. at xxvi, 74 .

8. See infra Part III.

9. See AMAN, supra note 1 at 124-27. See also DAVID HARVEY, A BRIEF HISTORY OF NEOLIBERALISM 74-86 (2005) [hereinafter NEOLIBERALISM]. See generally GovERNMENT BY CONTRACT: OUTSOURCING AND AMERICAN DEMOCRACY (Jody Freeman \& Martha Minow 
Understanding the domestic faces of globalization-represented in this article primarily by welfare recipients-requires both of these perspectives. But welfare is not the only context that is instructive in this regard. Immigration and privatized prisons offer other relevant cases (though beyond the scope of this article). For example, in the context of immigration, a global perspective on domestic affairs draws our attention to the factors affecting migrants' choices regarding destination, the decision to migrate in the first place, and the question of admission to the new host country. But it does not stop there. A domestic perspective on globalization reminds us that admission is not the same as inclusion. In the United States, some of the problems facing immigrants are also the problems of the working poor and other populations at the social margins who are particularly affected by reductions in social services. ${ }^{10}$ Thus, welfare eligibility in many states increasingly depends upon judgments rendered by private companies. ${ }^{11}$ Prisoners held in privately managed facilities are also subject to companies' business interests and their need to satisfy their shareholders. ${ }^{12}$ Political debates that connect globalization to government regulation, especially outsourcing and privatization, usually treat globalization as if it were synonymous with the market, often politically packaged with (or as) ideological assertions about the virtues of markets over bureaucracy. The issue of immigration is intertwined with these premises in several ways. The regulation of immigration tends to privilege work, particularly skilled work; under other circumstances, the argument against migration is waged on the grounds of unfair (i.e., under-selling) competition for jobs with the native born. Immigration policy sets heavy bars against migrants who might require government-subsidized social services..$^{13}$ These are essentially efficiency arguments entirely consistent with marketized

eds., 2009) (describing the shift of federal and state government to work with private organizations since the New Deal era); DAVID HARVEY, THE ENIGMA OF CAPITAL AND THE CRISES OF CAPITALISM (2010).

10. See generally Alfred C. Aman, Jr. \& Graham Rehrig, The Domestic Face of Globalization: Law's Role in the Integration of Immigrants in the United States (2011), available at http://ssrn.com/abstract $=1945825$; THE NEW POVERTY STUDIES: THE ETHNOGRaPHy OF POWER, POLITICS, AND IMPOVERISHEd PEOPLE IN THE UNITED STATES (Judith Goode \& Jeff Maskovsky eds., 2001); LoÏC WACQUaNT, PUNISHING THE POOR: THE Neoliberal Government of Social InSECURITy (Duke Univ. Press, English Language ed. 2009).

11. See, e.g., infra text accompanying note 83.

12. See Alfred C. Aman, Jr., Globalization, Democracy, and the Need for a New Administrative Law, 49 UCLA L. REv. 1687, 1711 (2002); Shymeka L. Hunter, More Than Just a Private Affair: Is The Practice of Incarcerating Alaska Prisoners in Private Out-Of-State Prisons Unconstitutional?, 17 ALASKa L. REv. 319, 328-29 (2000).

13. Aman \& Rehrig, supra note 10 , at 4. 
approaches to other areas of social policy. But immigration also challenges those approaches. Anti-immigration critics blame immigrants for restricting the work opportunities of the native born, but not the policies that produce job scarcity. They blame immigrants for working, but also for not working.

A similar story can be told for prisoners, especially those held in private prisons. ${ }^{14} \mathrm{~A}$ domestic perspective on globalization shows states eager to compete in the global economy by attracting new investment and jobs to their jurisdictions. To engage in this competition, they often use as their political currency the promise of low taxes, a skilled workforce, and low regulatory costs-including off-loading the costs of maintaining and managing prisons. ${ }^{15}$ Such global aspirations have coincided with an explosion of population growth in prisons due largely to drug laws and approaches to punishment embodied by so-called three strike laws. ${ }^{16}$ One way to build new prisons and not raise taxes is to outsource the construction and management of these prisons to private firms. ${ }^{17}$ Private firms pay the upfront construction costs and amortize them over a number of years; new prisons can be built without significantly affecting state taxes or budgets. ${ }^{18}$ Private firms usually cut

14. See generally BERnARD E. HARCOURT, THE ILlusion OF FREe MARKETS: PUNIShMENT AND THE MYTH OF NATURAL ORDER 233-39 (2011); Dolovich, supra note 5 (arguing that comparative efficiency in the realm of outsourcing government operations serves as a rhetorical device that excludes some concerns altogether and reframes others in ways inconsistent with its own priorities); Anne Larason Schneider, Public-Private Partnerships in the U.S. Prison System, in PUblic-Private Policy ParTnerships 199 (Pauline Vaillancourt Rosenau ed., 2000).

15. See Dolovich, supra note 5, at 139. See also Clifford J. Rosky, Force, Inc.: The Privatization of Punishment, Policing, and Military Force in Liberal States, 36 CONN. L. REV. 879, 929 (2004) (summarizing the pro-privatization and cost efficiency argument for state prison systems).

16. See HARCOURT, supra note 14, at 202. These and other approaches have led to an explosion of prison populations around the U. S. and various new means for managing these prisoners as well as building and financing the new prisons now required to hold them. See id. at 196-208. Indeed, as Bernard Harcourt has pointed out, "In 2008, the United States . . incarcerated more than one percent of its adult population-the highest rate in the world, five times the rate in England and twelve times the rate in Japan, and the highest raw number in the world as well." Id. at 198. And more than $10 \%$ of African American men between the ages of 20-34 were behind bars. Id.

17. See Alfred C. Aman, Jr., Privatization and Democracy: Resources in Administrative Law, in Government BY CONTRACT: OUTSOURCING AND AMERICAN DEMOCRACY, supra note 5, at 261, 274-75; Dolovich, supra note 5, at 142-43.

18. See generally Ira P. Robbins, The Legal Dimensions of Private Incarceration, 38 AM. U. L. REV. 531, 625-35 (1989) (discussing a variety of ways in which government agencies contract for private financing for the construction and operation of new correctional facilities). 
costs in other ways, as well-for example, by employing nonunion guards, who are paid nonunion wages and hired in lower numbers. ${ }^{19}$

A global perspective on domestic law shows that the firms to which this work is outsourced are, in most instances, multinational corporations that operate private prisons around the world. ${ }^{20}$ Moreover, though the theory behind outsourcing is that a state can thereby take advantage of market competition and get the best price, there are often only a few firms that regularly compete for such contracts, dominating the field. ${ }^{21} \mathrm{~A}$ kind of delegation occurs not just to the private sector generally, but more specifically to a handful of firms. A global perspective reveals that outsourcing often means trading a government monopoly for a private one or at least a private oligopoly. The expertise that these firms develop internationally in such public-private management arrangements can create its own pressures for privatization at the international level. ${ }^{22}$ Welfare policy also involves parallels to the economic logic behind privatized prisons as well as to immigration, referenced above. At the federal level, for example, the Welfare Reform Act of 1996 eliminated welfare assistance to immigrants; ${ }^{23}$ the provisions excluding immigrants from welfare

19. Martin E. Gold, The Privatization of Prisons, 28 URB. LAW. 359, 383-84 (1996).

20. The GEO Group, Inc. employs over 18,000 employees and operates and/or owns over one hundred facilities on several continents. Locations, GEO, http://www.geogroup.com/locations (last visited Mar. 3, 2013). Corrections Corporation of America (CCA) operates within the United States, Puerto Rico, and the U.S. Virgin Islands. About Us, CCA, http://www.cca.com/about/ (last visited Mar. 12, 2013). See generally Patrice A. Fulcher, Hustle and Flow: Prison Privatization Fueling the Prison Industrial Complex, 51 WASHBURN L.J. 589, 601-03 (2012).

21. Stephen Raher, The Business of Punishing: Impediments to Accountability in the Private Corrections Industry, 13 RicH. J.L. \& PUB. INT. 209, 214 (2010); Ahmed A. White, Rule of Law and the Limits of Sovereignty: The Private Prison in Jurisprudential Perspective, 38 AM. CRIM. L. REV. 111, 134 (2001).

22. For example, many developing nations are now contracting water services to large transnational corporations. See Kristin L. Retherford, Note, Regulating the Corporate Tap: Applying Global Administrative Law Principles to Achieve the Human Right to Water, 88 IND. L.J. (forthcoming Fall 2013) (manuscript at 10, 13.17) (on file with the author) (discussing privatization of water services in Bolivia and Indonesia). These firms have placed pressure on the World Trade Organization to liberalize the water market in developing nations, which would effectively commodify water. See Rona Nardone, Note, Like Oil and Water: The WTO and the World's Water Resources, 19 CONN. J. INT'L L. 183, 195-97 (2003). See generally Bryant Walker Smith, Water As A Public Good: The Status of Water Under the General Agreement on Tariffs and Trade, 17 CARDOZO J. INT'L \& COMP. L. 291 (2009) (discussing whether water is a "product" subject to the WTO's General Agreement on Tariffs and Trade (GATT)).

23. Welfare Reform Act of 1996, Pub. L. No. 104-193, 110 Stat. 2105 (codified at 42 U.S.C. $\S \S 601-17(2012))$. 
amounted to a significant portion of the cost savings usually attributed to that Act. ${ }^{24}$

These and other market driven reforms are in many ways a response to a particular conception of globalization as economic pressure resulting from global economic competition. ${ }^{25}$ They are in part attempts by states to be as competitive as possible in their drive to attract new capital to their state as well as retain the investments already there. The reforms are also the culmination of experiments occurring throughout the country, experiments that place more and more faith in markets and private providers than in traditional public sector employees and facilities. ${ }^{26}$ Privatization of social services, which in this context means the outsourcing of the administration of social services to private entities, is the primary zone where we can expect to find an active exchange between global and domestic perspectives. Specifically, the new relationships between private and public actors created by the marketization of borders, prisons, and welfare, teach us important lessons about the domestic fronts of globalization and-in that lightwe may see the potential for new kinds of law reform that can correct the limitations of a binary conception of government and markets as if these were mutually exclusive. A role for law reform exists, particularly law reform that can help create new forums for deliberation and stakeholder participation when it comes to decisions regarding whether and how to outsource. Creating new opportunities for political participation would be in keeping with the idea of Polanyi's "double movement."27

Looking ahead to those future developments, it bears noting that there are other models of globalization beyond the neoliberal one that predominates today. ${ }^{28}$ If we are, in Polanyi's terms, to re-embed these market means into society, law has an important role to play in creating

24. See generally Alex Stepick, There Is More to Life Than a Glass of Water: Immigration in the Contemporary United States, 108 AM. ANTHROPOLOGIST 392 (2006).

25. See NEOLIBERALISM, supra note 9, at 64-89; AMAN, supra note 1, at 34-35.

26. However, as Henry Giroux has written, "market-driven utopias . . . have implored us to turn away from the public realm as a terrain for improvement and change, to cut our losses there and limit our involvements, and to instead encourage individual responsibility, personal initiative, and the central-ity of people's private activities. Our social order . . . may not be perfect but it is good enough." HENRY A. GIROUX, PUBLIC SpaCeS, Private LIVES: Democracy Beyond 9/11, 113 (2003). See also Alfred C. Aman, Jr., Law, Markets and Democracy: A Role for Law in the Neo-Liberal State, 51 N.Y.L. ScH. L. REV. 801, 806 (2007) (arguing that a global perspective on these domestic reforms, along with a domestic perspective on their global implications will help us understand such trends and their limits).

27. See POLANYI, supra note 3, at 79-80.

28. See, e.g., Peter Evans, Is an Alternative Globalization Possible?, 36 POL. \& Soc'Y 271 (2008). 
opportunities for stakeholders to go beyond narrow cost questions and to pragmatically and flexibly experiment with approaches that offer fresh solutions to the need for efficient and fair outcomes. Law can provide the mechanisms and the forums for working out the negotiation of public and private interests in the political arena. ${ }^{29}$ Understanding how market means affect the substantive provisions of the programs they are designed to deliver requires a different way of thinking about globalization. In relation to social services, it requires a translation and an appreciation of the actual effects of the market in action on the substantive goals of the social services program involved. ${ }^{30}$ If, for

29. See generally AMAN, supra note 1; GOVERNMENT BY CONTRACT: OUTSOURCING AND AMERICAN DEMOCRACY, supra note 9.

30. See Howard Erlanger et al., Is It Time for a New Legal Realism?, 2005 WIS. L. REV. 335 (2005). The "New Legal Realism" is an emerging approach to law that attempts to incorporate interdisciplinary studies and empirical analysis into legal policy considerations. As Professor Erlanger states, "[l]ike the original Realists, who also sought to use social science in service of advancing legal knowledge, new legal realist scholars bring together legal theory and empirical research to build a stronger foundation for understanding law and formulating legal policy." Id. at 337. The New Legal Realists emphasize a "Bottom-Up" approach to empirical study:

The concept of "bottom-up" legal scholarship captures a combination of important aspects of NLR's [New Legal Realism] approach to research. First, at a methodological level, a bottom-up approach requires that assertions about the impact of law be supported by research at the "ground" level. This in turn requires that we rely on (or actually undertake ourselves) empirical research rather than using projections based simply on our theories or individual experiences. A bottom-up approach takes an expansive and open-minded view of the impact of law, and also includes within its purview a wide range of socio-economic classes and interests. Indeed, at times, this approach will reach outside of the boundaries of formal legal processes and institutions altogether to examine other forms of regulation and ordering. In order to do this, researchers will need to use empirical tools to help them move beyond formal categories, and they will have to remain skeptical about the impact of formal law. All of these admonitions can be understood simply as tenets of doing good social science research, because they seek to limit the degree to which unexamined assumptions made by researchers wind up blinding them to important parts of the picture they are studying.

Id. at 339-40. See also Victoria Nourse \& Gregory Shaffer, Varieties of New Legal Realism: Can A New World Order Prompt A New Legal Theory?, 95 CORNELL L. REv. 61 (2009) ("[arguing] that law cycles recursively over time between the world and legal institutions, which is why empirical and historical inquiry is essential to understanding law's actual operation, its failures and successes."). But see Thomas J. Miles \& Cass R. Sunstein, The New Legal Realism, 75 U. CHI. L. REv. 831, 850-851 (2008) (discussing the New Legal Realism and offering a cautious assessment and general qualification: "П] and the lawyers they train must often make normative evaluations of legal rules and institutions on the basis of only partial information. They ought to do so with full awareness of the limitations of their analyses ... The New Legal Realism remains in its infancy. As it grows, we will learn much more."). 
example, the modernization of welfare eligibility is all about improving the access of potential welfare recipients to benefits, have these reforms in fact worked the way they were intended?31

But perhaps even more fundamentally, the marketization of programs designed to serve vulnerable populations makes highly visible the line between law and society, between the public and private sectors, and between the federal and local government. The situation of welfare recipients is shaped at the crux of a number of issues central to the domestic face of globalization: the limits of the market (including markets for labor), the limits of law, and the limits of power at the various social and political levels of government and governance. Marketized social programs also make more visible new forms of identity, social mobility, and vulnerability, as the politics of globalization take shape around and through them.

This article will look at privatized social services primarily from the standpoint of finding new ways of understanding the role law can play to re-embed marketized administrative approaches into the public sector. The administration of these government services and duties does not involve complete deregulation; therefore, these processes do not totally separate the state from the market. ${ }^{32}$ New relationships are forged; new mixes of public and private power are created. By understanding the interactions involved in the privatization of domestic social services more fully, we can suggest law reforms that can re-embed the market into the state in new and effective ways. As we shall see, this means rethinking the status of the service recipient-whom privatization tends to rewrite as a product rather than a client or stakeholder. This is a serious limitation, as the case study will show. Finding new possibilities for marketized public-private relationships is essential for re-embodying service recipients as citizens in the full sense of the term-i.e. in terms of their access to the full range of social and political protections. ${ }^{33}$

31. See infra Part II.

32. See POLANYI, supra note 3 , at 71 . Of course, in today's world no one would realistically suggest that the market and the state can be completely separate. You need law to create property rights, enforce contracts and the like. But the question that does arise, particularly in the context of vulnerable populations, is the extent to which you need law to not only help increase efficiency but protect the rights of the individuals involved, be they prisoners, immigrants or welfare recipients. Part III deals with legal approaches that do precisely that in the context of welfare assistance. See infra Part III.

33. See Jon D. Michaels, Note, To Promote the General Welfare: The Republican Imperative to Enhance Citizenship Welfare Rights, 111 YALE L.J. 1457, 1491-95 (2002) (arguing that republican values inherent in American constitutional democracy imply that "the right to minimal resource protection" is "necessary for political and civic participation"). 
In Part II, a discussion of welfare reform prefaces the Indiana case study. In the case study, I examine further not only the use of market concepts and processes to carry out what were previously governmental tasks, but also the areas where the translation of business approaches into governmental actions broke down-places where market approaches to welfare applications did not or could not adequately translate fully into the governmental tasks at hand. The attempts at modernizing welfare administration in Indiana have relied heavily on the efficiencies a private corporation could bring to welfare eligibility decisions. There was, at least initially, a binary assumption built into these modernization reforms. Market techniques and private providers were to replace traditional government approaches that relied on face-to-face contact by government employees. Government modernization of benefits was to occur by outsourcing the administration of the welfare program to a private entity rather than insourcing modernization techniques into the government offices in question.

With such binary thinking came the expectation that the private sector would be, for the most part, automatically better than the government itself at developing these new approaches. ${ }^{34}$ The market-government binary that seemed very much to shape the early thinking of how welfare could be modernized presumptively favored not only new technological approaches, but also a conception of the task at hand that treated welfare applicants as essentially a reasonably homogeneous population of customers who could now fend for themselves more easily with computer access and 800 numbers. As we shall see, however, such a characterization can all too easily depoliticize many of the highly individualized, personal issues involved that require more than an abstract concern with access, while at the same time adding an aura of objectivity to the outcomes achieved. More important, as this case will also show, the state of Indiana was IBM's client and, though the burdens of this contract were felt acutely by welfare recipients, only Indiana could challenge IBM's performance of the contract, which it ultimately did when it sued for breach of contract. Welfare applicants and recipients, however, had to work through the

34. The government's contract did in theory reserve final decision-making to the government and it did retain field offices in all ninety-two counties. Daniels Signs $\$ 1$ Billion Welfare Outsourcing Deal, WTHR.COM (Dec. 27, 2006), http://www.wthr.com/story/5864292/ daniels-signs-1-billion-welfare-outsourcing-deal?clienttype=printable. See also Indiana v. Int'l Bus. Machs. Corp., No. 49D10-1005-PL-021451, slip op. at 13-14 (Marion Super. Ct., Civ. Div. 10 July 18, 2012) (findings of fact, conclusions of law, and judgment for IBM). However, those offices would become woefully understaffed, compared to what they were before the contracting out of this program. Problems Noted as FSSA Privatization Begins, WTHR.com, http://www.wthr.com/global/story.asp?s=6732281\&ClientType=Printable. 
state rather than protecting their rights as third-party beneficiaries of this contract. To this extent, they were really neither clients nor even customers, but the presumed recipients of an abstract product called access. Even more important, the ability of welfare recipients to access their benefits in a more efficient way was a form of wealth creation for the state, allowing it to lower its costs and labor force. In reality, however, these new forms of access were not successful in many cases. The more the method of delivery of these services became disconnected from outcomes in actual cases, the less such a contract could serve the very population for which it was intended.

Welfare applicants, however, were neither customers nor IBM's products. And legally speaking they were not clients either-they had no independent rights under the contract as third-party beneficiaries. ${ }^{35}$ They were, of course, citizens in dire economic need. They were a diverse group, consisting of the elderly, disabled, children, single parents, and individuals for whom a job may not have been available due to their skill set or the relatively depressed state of the economy. Moreover, given the fact that this case involves individuals at the bottom of the economic and often educational ladder as well, the digital divide when it comes to computer access and know-how can be quite pronounced. ${ }^{36}$ Carried too far, a primarily technological approach to welfare eligibility makes technology itself a filter-since many potential recipients may not have access to computers or even telephone call centers. ${ }^{37}$ These circumstances risk substituting technological, cost efficient means for substantive benefits. As Professor Ronen Shamir has written in his critique of corporate social responsibility, we need a theory of translation when we apply neoliberal reform to traditional forms of government regulation. "Such a theory must come to grips with, and identify the pitfalls of, working within the non-governmental organization institutional paradigm, because the latter is heavily biased

35. See discussion infra Part III.

36. See Bryan Corbin, RV to Help With Welfare, Medicaid, Food Stamp Concerns at Deaconess Family Practice Today, Courierpress.COM (Jan. 22, 2009), http://www.courierpress.com/news/2009/jan/22/rv-help-welfare-medicaid-food-stamps-

concerns/?print=1; e.g., Perdue v. Murphy, 915 N.E.2d 498, 501 (Ind. Ct. App. 2009) (describing the difficulty that one disabled woman had with using the modernized system deployed by the FSSA in 2007).

37. Tennessee, for example, distributes a portion of their Medicaid benefits through a kind of lottery system, in which benefits are given to the those qualified callers who are able to dial-in to call centers before others. Abby Goodnough, Tennessee Race for Medicaid: Dial Fast and Try Again, N.Y. TIMES, Mar. 25, 2013, at A1. 
toward the corporate hegemonic model of organization and implementation." ${ }^{8}$ As a consequence,

[We] must also worry about the way the perceived grievances of oppressed, marginal, and exploited populations . . . are transformed into a meaningful political and legal voice by relatively affluent and secured ... experts who often speak the language of and deploy the instruments of hegemonic rational organizational and managerial systems characteristic of contemporary capitalism. . . . [T] here seems to have emerged a hegemonic cultural-institutional model concerning the 'right way of doing things.' This right way of doing things purports to be divorced from actual substance as it deals with models, blueprints, protocols, procedures, key words, and key concepts alone. ${ }^{39}$

Welfare modernization in Indiana illustrates the problems Shamir identifies. As originally conceptualized and proposed, the welfare reforms focused primarily on cost savings made possible by technologically sophisticated means for assessing welfare eligibility, rather than, quite literally, focusing on the welfare of the individuals involved. 40

The elimination of perceived corruption in the welfare eligibility process was also a goal of modernization. ${ }^{41}$ Reliance on market actors and the best business practices they could implement meant that face-to-face contact with government caseworkers in repeat situations would be drastically reduced. The reasoning behind making the new system relatively impersonal and decentralized was that the system was likely to become more objective. ${ }^{42}$ Caseworkers were assumed to be prone to favor applicants and override eligibility criteria at their own discretion. Critics of the existing system also argued that the face-to-face system was susceptible to mistakes and fraud. Moreover,

38. RONEN SHAMIR, CORPORATE SOCIAL RESPONSIBILITY: A CASE OF HEGEMONY AND COUNTER-HEGEMONY IN LAW AND GLOBALIZATION FROM BELOW 113 (Bonaventura de Souse Santos \& Cesar A. Rodriguez-Garvito, eds., 2005).

39. Id.

40. Jerry L. Mashaw, Administrative Due Process and Social-Cost Accounting, 9 HoFsTRA L. REV. 1423, 1427 (1981); Michaels, supra note 33. See also infra note 154 and accompanying text.

41. See infra note 76.

42. Indiana v. Int'l Bus. Machs. Corp., No. 49D10-1005-PL-021451, slip op. at 32, 32 n.51 (Marion Super. Ct., Civ. Div. 10 July 18, 2012) (findings of fact, conclusions of law, and judgment for IBM). 
they believed that the move to private providers would significantly decrease the number of government employees on the state's payroll. As we shall see, most welfare caseworkers became employees of the companies to which the welfare program was outsourced. ${ }^{43}$

In short, the main goals of Indiana's modernization approach were to increase access for welfare applicants through computers and call centers, and in the process lower the number of government workers involved by moving public employees to the private payrolls of the private corporations with whom the government contracted. This lowered the costs of administering the welfare program, while presumably increasing the accuracy of the decisions made and eliminating much of the fraud that had previously occurred. Market perspectives and best practices approaches, especially computer access and telephone call centers, privately run, would now substitute for most of the face-to-face casework that had previously typified the now discredited welfare eligibility approaches used by Indiana in the past.

This is where the outsourcing process began. What is remarkable about the evolution of welfare modernization in Indiana, however, is that various forms of what Polanyi might identify as the double movement in action helped refocus welfare modernization on substantive outcomes and less on new, efficient ways of servicing the "customers" involved. Unforeseen events also intervened, including the massive flooding in parts of Indiana in 2007 and the Great Recession of 2008. In the final analysis, however, the state may initially have embraced the binary view that markets and market approaches are superior to government when it came to administering welfare at the state level, but ultimately the state backed away from so binary a view, seeking instead to devise and implement what it called a more hybrid approach to the administration of welfare benefits. ${ }^{44}$

The Indiana case is interesting in part because the state itself ultimately took some corrective action when it became clear the contract to which it entered was not working the way it had hoped ${ }^{45}$-a double movement of sorts. ${ }^{46}$ Moreover, from the time this approach was suggested political pushback, in the form of legislation, began. ${ }^{47}$ In

43. See infra note 106 and accompanying text.

44. See infra note 209 and accompanying text.

45. See id.

46. See POLANY, supra note 3 , at $79-80$ (referring to the social history in the nineteenth century as a "double movement").

47. From 2006 to 2009 , the Indiana legislature introduced a plethora of bills addressing the privatization of government services and functions. Some of the proposals were uninspired. See S. 425, 115th Gen. Assemb., 1st Reg. Sess. (Ind. 2007) ("A contract for services may not be entered into for a period of more than four (4) years unless a statute specifically provides otherwise."). Others sought to implement comprehensive 
2007 , the state even enacted a law requiring state agencies to allow for public comment and testimony at a public hearing and obtain approval from the state budget committee before it enters into a private contract lasting at least four years and worth over $\$ 10$ million, and in which a private vendor provides services formerly performed by state employees. ${ }^{48}$

The double perspective of a global view of domestic reform coupled with a domestic view of globalization helps us to understand more fully these and other details of welfare reform in Indiana. These perspectives reveal how marketized administrative approaches to welfare dis-embed the state from the market yet, in the process, create the conditions for re-embedding the state. In Indiana, as this article will detail, the re-embedding process created new relationships between citizens and government, as well as between the public and private sectors now involved in welfare administration. As a result we can better see and understand how the double movement described by Polanyi might work-but after privatization, the return movement was, perhaps surprisingly, initiated by the state. At the crux of these processes may lie the transformation of the neoliberal state and an alternative domestic approach to globalization.

\section{WELFARE REFORM}

The Personal Responsibility and Work Opportunity Reconciliation Act of 1996 ("Welfare Reform Act") 49 was passed by the United States Congress as an avowed program of economic and social change: it was all about work-"workfare not welfare" was explicitly formulated to eliminate dependency. ${ }^{50}$ To that end, the bill mandated work. ${ }^{51}$ The Welfare Reform Act also devolved power and responsibility to the states.

procedures to accompany privatization, such as the creation of privatization review committee that would oversee a crude form of agency rule-making procedures found in the Administrative Procedure Act, 5 U.S.C. 500 et seq. (2012). See H.B. 1062, 115th Gen. Assemb., 1st Reg. Sess. (Ind. 2007); S.B. 113, 114th Gen. Assemb., 2d Sess. (Ind. 2006); S.B. 241, 114th Gen. Assemb., 2d Sess. (Ind. 2006); S.B. 63, 115th Gen. Assemb., 1st Reg. Sess. (Ind. 2007); H.B. 1079, 114th Gen. Assemb., 2d Sess. (Ind. 2006); H.B. 1215, 114th Gen. Assemb., 2d Sess. (Ind. 2006); H.B. 1325, 114th Gen. Assemb., 2d Sess. (Ind. 2006); H.B. 1026, 115th Gen. Assemb., Reg. Sess. (Ind. 2007).

48. S.B. 83,115 th Gen. Assemb., 1st Reg. Sess. (Ind. 2007) (codified at IND. CoDE $\S$ 4-12-13 (2008)).

49. Personal Responsibility and Work Opportunity Reconciliation Act of 1996, Pub. L. No. 104-193, 110 Stat. 2105 (codified at 42 U.S.C. $\S \S 601-17$ (2012)).

50. See 42 U.S.C. $\$ 601$ (2012).

51. Id. at $\S 607$. For a critical discussion of the dependency rationale, see Jon Michaels, Deforming Welfare: How the Dominant Narratives of Devolution and Privatization Subverted Federal Welfare Reform, 34 SETON HALL L. REV. 573, 600-04 (2004). 
Federal money was to go back to the states in the form of block grants where states could, within broad guidelines, use the money as they saw fit. ${ }^{52}$ Experimentation was a part of the plan. ${ }^{53}$ Some states used it to create job training programs; ${ }^{54}$ some used it to fund programs designed to encourage character building and a deeper commitment to religious faith-so called faith-based initiatives. ${ }^{55}$

But many states that chose to continue to provide direct payments to the poor decided to outsource these responsibilities to multinational corporations (MNCs) such as Lockheed Martin, IBM, or Maximus Corp. ${ }^{56} \mathrm{MNCs}$ in some states took over the responsibility of determining who should be on the welfare rolls and who should be eliminated pursuant to state contracts and state oversight. ${ }^{57} \mathrm{~A}$ global perspective on outsourcing welfare administration reveals that, not unlike the drive to privatize prisons, the driving forces behind this shift to market actors

52. See 42 U.S.C. $\$ \S 601$ (a) (stating that the purpose of the legislation is to "increase the flexibility of the States."); 42 U.S.C. $\S \S 603-04$. See also Michaels, supra note 51, at 600-04.

53. See Wendy A. Bach, Welfare Reform, Privatization, and Power: Reconfiguring Administrative Law Structures from the Ground Up, 74 BROOK. L. REV. 275, 279-80 (2009).

54. See Barbara L. Bezdek, Contractual Welfare: Non-Accountability and Diminished Democracy in Local Government Contracts for Welfare-to-Work Services, 28 FORDHAM URB. L.J. 1559, 1564 (2001) ("Indeed, much of what the new model of welfare-to-work staff does is to assign welfare clients to job readiness or work-training vendors."); Matthew Diller, The Revolution in Welfare Administration: Rules, Discretion, and Entrepreneurial Government, 75 N.Y.U. L. REV. 1121, 1181-82 (2000).

55. See 42 U.S.C. $§ 604 a$, although the statute explicitly stated, "[n]o funds provided directly to institutions or organizations to provide services and administer programs under subsection (a)(1)(A) of this section shall be expended for sectarian worship, instruction, or proselytization." $\$ 604 a(j)$.

56. See Bill Berkowitz, Prospecting Among the Poor: Welfare Privatization 15, 16 (2001), available at http://www.arc.org/pdf/296bpdf.pdf; M. BRYNA SANGER, THE WELFARE MARKETPLACE: PRIVATIZATION AND WELFARE REFORM 2, 74-76 (2003); Bach, supra note 53, at 278 ("[T]he PRA joined a rising tide of initiatives to 'reinvent government' by using private sector tools and entities to free government from the constraints of what was seen as excessive bureaucracy and constrictive civil service rules."); Diller, supra note 54, at 1147, 1180-83 ("Some states and counties further have devolved welfare administration to private contractors."); Dru Stevenson, Privatization of Welfare Services: Delegation by Commercial Contract, 45 ARIZ. L. REV. 83, 89 (2003); Mark Carl Rom, From Welfare State to Opportunity, Inc.: Public-Private Partnerships in Welfare Reform, in Public-PRIVATE POLICY PARTNERShIPS, supra note 14, at 171-76.

57. See Bezdek, supra note 54, at 1566 (2001) ("The Act now authorizes states to employ private entities to conduct intake and make eligibility determinations-traditional gate-keeping functions of any benefits program-most often identified with the legal protections developed under AFDC. Although nonprofits have been involved in service delivery for decades, the Act has brought for-profit enterprises into social services functions far beyond their prior limited roles as contractors for data systems."); Rom, supra note 56 , at $171-76$. 
in the context of welfare administration was the belief that market approaches to eligibility and the incorporation of business best practices would make states more efficient and globally competitive by lowering welfare administration costs and reducing errors and corruption. ${ }^{58} \mathrm{~A}$ global perspective on domestic law reveals that by privatizing this aspect of welfare administration, the Welfare Reform Act also had the ironic effect of re-centralizing these decisions, not at the federal level, but at the multinational corporate level. ${ }^{59}$ The underlying rationale was that market approaches and best business practices were the best way to reform what usually was seen as inefficient and-as we shall see in the case on Indiana-even corrupt delivery systems; ${ }^{60}$ though what constituted corruption may have also included the exercise of discretion by individual caseworkers. ${ }^{61}$ Also implied in such outsourcing in the welfare context was the idea that business approaches to welfare administration would help encourage individual self-sufficiency and independence.

In short, a MNC was substituted for state and federal government; uniformity was achieved, but the kind of uniformity that comes with finding an efficient way of proceeding. It was a type of uniformity that would allow citizens of the state to minimize their costs and taxes, but also enable the shareholders of the companies involved to maximize their profits. They could do this by doing what they did best: streamlining and computerizing their services. Computers and call centers replaced caseworkers. The domestic face of a welfare recipient was thus transformed from a citizen to an output or a product-one that either deserved benefits or one that did not, and, in a sense, a customer as well, in that they were to receive this information of entitlement or non-entitlement promptly and with a minimum of face-to-face contact. ${ }^{62}$

58. See E.S. Savas, Privatization: The Key to BetTer Government 112 (1987); Matthew Diller, Form and Substance in the Privatization of Poverty Programs, 49 UCLA L. REV. 1739, 1743-44 (2002); Jonathan Walters, The Welfare Bonanza, Governing THE STATES AND LOCALITIES, (January 2000), www.governing.com/topics/health-humanservices/Welfare-Bonanza.html.

59. IBM's role in planning and implementing Indiana's welfare modernization plan is a case-in-point. See infra Part II.A.

60. See infra Part II.A.

61. In some cases, real corruption resulted in the unlawful distribution of welfare benefits. See infra note $\mathbf{7 6}$ and accompanying text. However, in other cases, caseworkers did not follow the "letter-of-the-law" in order to avoid some of the harsh consequences that recipients might have otherwise faced for failing to observe the minutiae of formal procedure. See Indiana v. Int'l Bus. Machs. Corp., No. 49D10-1005-PL-021451, slip op. at 32, 32 n.51 (Marion Super. Ct., Civ. Div. 10 July 18, 2012) (findings of fact, conclusions of law, and judgment for IBM).

62. See Int'l Bus. Machs. Corp., No. 49D10-1005-PL-021451, slip op. at 32, 32 n.51; Perdue v. Murphy, 915 N.E.2d 498, 500-02 (Ind. Ct. App. 2009). 
A domestic perspective on these global efficiency rationales, however, must begin with some skepticism. Welfare benefits have a long and complicated history, especially beginning with the turn to neoliberalism that occurred in the Reagan-Thatcher era. ${ }^{63}$ Indeed, welfare recipients have not only been analyzed in multiple ways, ${ }^{64}$ but ridiculed as well, with the infamous image of the so-called "welfare queen." 65 Along with recent welfare to work reforms, others increasingly have relied on the criminal law to minimize anticipated corruption. ${ }^{6}$ Against this political backdrop, the need for welfare has been increasing. The disparity in incomes between the "haves" and "have-nots" has grown dramatically, not only in the United States, but globally as well. ${ }^{67}$ Moreover, poverty rates have risen substantially in the United States, especially given the slow pace of economic recovery after the financial meltdown of 2008.68 Is the modernization of welfare intended primarily to address the increasing needs of individuals in economic crisis by increasing access to the system, or is it designed primarily to lower costs, quite apart from the substantive impact the means of lowering costs might have on individual welfare applicants? To what extent do the reforms involved take into account the differences in welfare applicants, recognizing that they include the disabled, the elderly, children, and individuals with various backgrounds, not all of which are computer literate or self-sufficient when it comes to analyzing the choices they may have to make? As the Indiana case shows, a largely binary approach to market approaches as opposed to a fully government administered program ultimately evolved into a hybrid public-private partnership with some formal and informal changes in law that offer some promise for the future and the beginnings of law reforms designed to re-embed the market into the state. ${ }^{69}$

63. See generally KaARYN S. Gustafson, ChEATING WELFARE: Public AsSistance AND THE CRIMINALIZATION OF POVERTY 17.50 (2011).

64. See, e.g., id. at 38; OSCAR LeWIS, FIVE FAMILIES: MEXICAN CASE STUdies IN THE CUlture of Poverty (1959); OfFice of Policy PlanNING and RESEarch, UNited States Department of Labor, THe Negro Family: THe CASE For National ACtion (1965); Oscar Lewis, The Culture of Poverty, in ON UNDERSTANDING POVERTY: PERSPECTIVES From THE SOCIAL SCIENCES 187 (Daniel P. Moynihan ed., 1968).

65. See GUSTAFSON, supra note 63, at 34-38.

66. Id. at 6-8.

67. See JoSEPH E. STIGLITZ, The PRICE OF INEQUALITY, at ix-xvi (2012).

68. Id.

69. See infra Part III. 


\section{A. Privatizing Welfare Administration in Indiana}

Indiana's welfare programs include the provision of food stamps, ${ }^{70}$ Medicaid, ${ }^{71}$ Temporary Assistance for Needy Families (TANF), ${ }^{72}$ and other assistance programs for the needy..$^{73}$ They are administered by the Family Social Service Administration (FSSA). According to a report issued by FSSA in 2006, distribution and management of welfare benefits in Indiana was among the worst in the United States, citing fraud as a persistent problem..$^{74}$

Between 2002 and 2006, at least fifteen caseworkers were arrested for fraud for illicitly obtaining food stamps and TANF benefits..$^{75} \mathrm{In}$ addition, "at least [twenty-one] 'outside conspirators' have illegally obtained benefits or committed some sort of fraud with the assistance of FSSA staff." 76 Moreover, high error rates were reported: 35.28 percent

70. 470 IND. Admin. Code art. 6 (2012). See generally IND. FAMILY \& Soc. SERVS. Admin., Supplemental Nutrition AssistanCe Program, www.in.gov/fssa/dfr/2691.htm (last visited Jan. 31, 2013) (describing Indiana's food assistance program).

71. See IND. CoDE $§ 12-15$ (2012) (Indiana provisions relating to Medicaid). Indiana provides other health care services in addition to Medicaid. See, e.g., IND. CoDE $\S 12-16$ (2012) (Payment for Health Services Other Than Medicaid); IND. CODE § 12-16.1 (2012) (Hospital Care for the Indigent); IND. CODE $§ 16.5$ (2012) (The Health Care Compact); IND. CoDE $§ 12-17.6$ (2012) (Children's Health Insurance Program). See also IND. FAMILY \& Soc. SERvs. Admin., ABout MEDiCaId/HEalth PlanS, www.in.gov/fssa/dfr/4502.htm (last visited Jan 31,2013$)$.

72. See IND. CODE $§ 12-14$ (Indiana provisions relating to TANF). See also IND. FAMILY $\&$ Soc. SERvs. ADMIN., TEMPORARY ASSISTANCE FOR NEEDY Families, www.in.gov/fssa/dfr/2684.htm (last visited Jan. 31 2013).

73. See IND. FAMILY \& Soc. SERvS. ADMIN., www.in.gov/fssa/index.htm (last visited Jan. 31, 2013) (listing services provided by the Indiana FSSA); ERIN LINVILLE, IND. FAMILY \& SOC. SeRvS. ADMIN., ELIGIBILITY MODERnIZATION: THE NEED FOR CHANGE 6-8 (2006) [hereinafter FSSA REPORT], available at web.courierpress.com/ecp/PDF/ EligibilityModernization081706.pdf (explaining the history of the FSSA and public assistance programs in Indiana).

74. See FSSA REPORT, supra note 73, at 4-5 ("In the past decade, Indiana ranked 50th in the percent reduction of citizens on welfare."). See also Indiana v. Int'l Bus. Machs. Corp., No. 49D10-1005-PL-021451, slip op. at 3-4 (Marion Super. Ct., Civ. Div. 10 July 18, 2012) (findings of fact, conclusions of law, and judgment for IBM); Press Release, Governor Mitch Daniels, State Ends Contract with IBM for Welfare Services (Oct. 15, 2009) [hereinafter State Ends Contract], available at http://www.in.gov/activecalendar/ EventList.aspx? fromdate $=1 / 1 / 2009 \&$ todate $=12 / 31 / 2009 \&$ display $=$ Month\&type=public\&eve ntidn $=61938 \&$ view $=$ EventDetails\&information_id $=124951 \&$ print=print.

75. See FSSA REPORT, supra note 73, at 19. See also OFFICE OF INSPECTOR GEN., ANNUAL REPORT (2006), available at http://www.in.gov/ig/files/OIG_2006_Annual_Report.pdf (detailing the office's role in prosecuting thirteen individuals for welfare-related fraud).

76. FSSA REPORT, supra note 73, at 19. Assisted by the Indiana Inspector General, several kinds of fraud cases were brought against both welfare recipients and caseworkers by Indiana prosecutors from 2005 to 2008 . Some welfare recipients failed to accurately report their income. See, e.g., David O. ThOMAS, LAKE COUNTY PUBLIC AssisTanCE Welfare Fraud, InSPECTOR 
in determining long-term care eligibility, 28.80 percent for TANF eligibility, and 12.04 percent for food stamps eligibility. ${ }^{77}$ FSSA also

GENERAL REPORT, 2005-12-0601 (Nov. 20, 2006) (individual provided falsified income information to FSSA to qualify for public assistance); DAVID O. THOMAS, MARION COUNTY PUBLIC ASSISTANCE FRAUD - 1, INSPECTOR GENERAL REPORT, 2005-06-0303 (Nov. 21, 2006) (failing to report income); DAVID O. THOMAS, MARION COUNTY PUBLIC ASSISTANCE FRAUD - 2, PRELIMINARY INSPECTOR GENERAL REPORT, 2005-06-0303 (Dec. 29, 2006) (reporting income as zero even though gainfully employed); DAVID O. THOMAS, MARION COUNTY PUBLIC ASSISTANCE FRAUD - 3, PRELIMINARY INSPECTOR GENERAL REPORT, 2005-06-0303 (Dec. 29, 2006) (failing to report gainful employment). Other individuals were arrested for assisting in attempting to apply for benefits using false information. See, e.g., David O. ThOMas, MaRION CounTY PUBLIC Assistance Fraud - 4, PRELIMTNARY InSPECtOR General RePORT, 2005-06-0303 (Dec. 29, 2006) (caseworker used false Social Security number and date of birth, but the correct address of felon to apply for food stamps); DAVID O. THOMAS, MARION COUNTY PUBLIC ASSISTANCE FraUD9, PRELIMINARY INSPECTOR GENERAL REPORT, 2005-06-0303 (Dec. 29, 2006) (reporting an income of zero even though actual income was over $\$ 100,000)$; DAVID O. THOMAS, MARION County PUBLIC ASSistance Fraud - 10, Preliminary INSPECTOR GENERAL RePORT, 2005-060303 (Dec. 29, 2006) (reporting an income of zero even though actual income was over $\$ 100,000$ ). Others were charged for using or selling fraudulent Electronic Benefits (EBT) cards-cards akin to ATM cards used to grant access to public assistance monies. See, e.g., DAVID O. THOMAS, MARION COUNTY PUBLIC ASSISTANCE FRAUD - 5, PRELIMINARY INSPECTOR GENERAL REPORT, 2005-06-0303 (Dec. 29, 2006) (using fraudulent EBT card); DAVID O. THOMAS, MARION COUNTY PUBLIC ASSISTANCE FRAUD - 6, 2005-06-0303 (Dec. 29, 2006) (using fraudulent EBT card); DAVID O. ThOMAS, MARION COUNTY PUBLIC ASSISTANCE FraUd - 7, PREIIMINARY INSPECTOR GENERAL REPORT, 2005-06-0303 (Dec. 29, 2006) (using fraudulent EBT card); DAVID O. THOMAS, Marion County PubuC Assistance Fraud - 8, Preliminary Inspector General Report, 2005-06-0303 (Dec. 29, 2006) (using and selling fraudulent EBT cards); DAVID 0. THOMAS, Marion County Public Assistance Fraud - 11, Preliminary InsPector General RePort, 2005-06-0303 (Dec. 29, 2006) (using fraudulent EBT card). Still others provided other forms of false information to increase the amount of benefits received. See, e.g., DAVID O. THOMAS, MEDICAID FRAUD, INSPECTOR GENERAL REPORT, 2008-04-0090 (Oct. 22, 2008) (failing to report that husband lived in home and that he provided income); DAVI O. THOMAS, DELEWARE COUNTY TANF FRAUD, INSPECTOR GENERAL REPORT, 2006-03-0128 (Apr. 16, 2007) (submitting forged documents, such as letters from landlords and leases). Charges have also been brought against caseworkers for assisting in fraud by failing to collect relevant information or distributing or selling unauthorized EBT cards that gave access to public assistance monies. See, e.g., DAVID O. THOMAS, EBT FRAUD, INSPECTOR GENERAL REPORT, 2005-06-0303 (Nov. 16, 2005) (establishing over twenty false accounts and issuing EBT cards to themselves); DAVID $O$. THOMAS, FORT WAYNE FSSA CASEWORKER FRAUD, INSPECTOR GENERAL REPORT, 2007-03-0055 (Apr. 25, 2007) (issuing EBT cards in friend's name and splitting the proceeds). Other caseworkers have been arrested for maintaining fictitious accounts and collecting the benefits for themselves. See, e.g., DAVID O. THOMAS, EBT FrAUD IN ALLEN COUNTY, INSPECTOR GENERAL REPORT, 2007-03-0062 (Nov. 20, 2007) (using fictitious people and keeping case files open to obtain benefits); DAVID O. THOMAS, DELAWARE COUNTY EBT FRAUD, INSPECTOR GENERAL REPORT, 2006-11-0321 (Apr. 16, 2007) (using falsified identities to obtain EBT benefits); DAVID O. ThOMAS, MARION COUNTY EBT FRAUD, INSPECTOR GENERAL REPORT, 2007-02-0046 (Mar. 29, 2007) (creating false case files and obtaining EBT cards when they were returned in the mail to the office).

77. FSSA REPORT, supra note 73, at 17. See also OFFICE OF THE GovernoR, INDIANA State Government Performance RePort: July - DeCEMBer 2006, at 7 (2007), 
faced potential criticism for inhibiting welfare beneficiaries from moving beyond the program to self-reliance. ${ }^{78}$ Indiana ranked last in the nation when it came to moving welfare recipients off welfare and to work as the 1996 federal law sought to do. ${ }^{79}$

When Governor Mitch Daniels was elected in 2004, he brought a market reform perspective to many areas of state government, welfare included. ${ }^{80}$ During his time as governor, he succeeded in privatizing various state functions, including certain functions of the prison system. $\mathrm{He}$ also outsourced the maintenance and operation of an Indiana toll road to a private firm. ${ }^{81}$ Welfare reform was also on his agenda. From the early days of his administration, he became particularly concerned that Indiana's welfare system was broken and "plagued by high error rates, fraud, wasted dollars, poor conditions for its employees, and very

available

http://in.gov/governorhistory/mitchdaniels/files/Performance_Report_4_(Jul-Dec_2006).pdf (report published on March 30, 2007 stating that "[i]n 2005 FSSA paid Food Stamps recipients $\$ 33.9$ million more than they were entitled" because of error). However, contrary to the reported instances above, not all recipients accused of fraud in the United States are attempting to game the system. While data for Indiana is unavailable, some studies have shown that much of the rule breaking in welfare law is done unknowingly as a result of recipients' ignorance or misunderstanding of the rules involved. See, e.g., GUSTAFSON, supra note 63 , at $3,129,161$. Additionally, caseworkers in Indiana have in some instances "bent the rules" not for personal gain but because they were sympathetic to the recipient. Int'l Bus. Machs. Corp., No. 49D10-1005-PL-021451, slip op. at 32.

78. See FSSA REPORT, supra note 73, at 18 . The report stated the issue as follows: As a result of the Deficit Reduction Act (DRA) of 2005, the federal government requires that states meet a workforce participation for TANF recipients of $50 \%$. In other words, $50 \%$ of Hoosier TANF recipients must be engaged in meaningful work-related activity, either working in a job or an Indiana Manpower and Comprehensive Training (IMPACT)-sponsored activity like volunteer work. (Certain TANF recipients, such as nonparent caretakers, are exempt from this calculation.) Indiana has historically had a workforce participation rate near $33 \%$. With Congress passing the TANF Reauthorization earlier this year, the $50 \%$ workforce participation requirement will be strictly enforced, and Indiana is at risk for failing to meet this requirement. This could cost the state up to $5 \%$ of its TANF block grant, or $\$ 10.3$ million, and the federal government could require that Indiana replace these lost federal funds with state funds.

79. See id. at 4-5 ("In the past decade, Indiana ranked 50th in the percent reduction of citizens on welfare."); Int'l Bus. Machs. Corp., No. 49D10-1005-PL-021451, slip op. at 3-4; State Ends Contract, supra note 74.

80. See Mitchell E. Daniels, Reforming Government Through Competition, in ANNUAL Privatization Report 2006: Transforming Government Through Privatization 10-13 (Leonard Gilroy ed., 2006) [hereinafter Daniels, Reforming Government], available at http://www.reason.org/apr2006; Jonathan Rauch, Mitch Daniels on How Libertarians Can Govern, THE BROWSER, http://thebrowser.com/interviews/mitch-daniels-on-howlibertarians-can-govern (last visited Jan. 31, 2013); Brian Doherty, Mitch Daniels: A Politician Who Likes Good Books, REASON.COM (July 7, 2010, 12:58 PM), http://reason.com/blog/2010/07/07/mitch-daniels-a-politician-who.

81. Daniels, Reforming Government, supra note 80, at 12. 
poor service to its clients." 82 Almost as soon as he became governor, he and other state officials began developing a welfare reform plan modeled on an approach that had recently been taken in Texas and called the "remote eligibility" model. ${ }^{83}$ The model allowed recipients to apply for public benefits through a variety of channels-by fax or mail, over the phone, through the Internet, or in person. Through one of these avenues, recipients would contact call centers, which would process all applications and renewals. Recipients could then track the progress of their applications online or through an automated phone system. ${ }^{84}$

Governor Daniels, in accord with his overall plans for privatization in various other governmental areas, ${ }^{85}$ sought to outsource the intake and processing of welfare claims as a remedy for the deficiencies he saw in Indiana's welfare programs. Under this model, Indiana citizens would

82. Int'l Bus. Machs. Corp., No. 49D10-1005-PL-021451, slip op. at 3.

83. In the mid-1900s, Texas began efforts to privatize eligibility determinations for fifteen welfare programs, known as Texas Integrated Enrollment System (TIES). Rom, supra note 56, at 175. A single firm would be responsible for operating and maintaining an "automated eligibility determination, single-state system." HEALTH AND HUMAN SERVICES COMmission, House BILl 3575: HeALTH AND Human SERVICES Eligibility System TRANSITION PLAN (October 2007) [hereinafter TEXAS PLAN], available at http://www.hhsc.state.tx.us/consolidation/IE/HB_3575_TransitionPlan.pdf. Although Texas' effort was approved by the federal government in 1997, the plan was opposed by many Texas public employees, and implementation stalled. Rom, supra note 56, at 175 . However, in 2003, Texas began to implement the TIES program when it passed House Bill 2292, directing the Health and Human Services Commission to "contract with at least one but not more than four private entities for the operation of call centers required by this section unless the commission determines that contracting would not be cost-effective." H.B. 2292, 2003 Leg., 78th Reg. Sess. $\$ 2.06$ (Tex. 2003) (codified at TEX. Gov'T CODE ANN. $\S 531.063$ (West 2003)). The four call centers would determine eligibility for and coordinate enrollment in TANF, food stamps, Medicaid, and other programs. Modernization efforts were reaffirmed in 2007 when the Texas Legislature passed House Bill 3575 , which established a legislative oversight committee to oversee with the transition to a modern eligibility system. H.B. 3575, 2007 Leg., 80th Reg. Sess. $§ 1$ (Tex. 2007) (codified at TEx. GOV'T CODE ANN. $\S 531.456$ (West 2007)). For a detailed overview of the history of Texas' modernization efforts, see generally TEXAS PLAN, supra. See also Christy G. Black \& Joe Barnett, A New Frontier for Welfare Reform, Brief Analysis No. 539, NAT'L CENTER FOR POL'Y ANALYSIS (Dec. 7, 2005), available at http://www.ncpa.org/pdfs/ba539.pdf ("Texas is about to roll out an ambitious program using private contractors to streamline the process of applying for public health and welfare programs.”); TEX. HEALTH \& HUMAN SERVS., IMPROVING THE APPLICATION PROCESS, http://web.archive.org/web/20121026204005/ http://www.hhs.state.tx.us/consolidation/IE/IE.shtml (last visited Feb. 26, 2013); Press Release, Tex. Health \& Human Servs., HHSC Estimates $\$ 646$ Million in Savings from Call Centers (June 30, 2005), available at http://www.hhs.state.tx.us/news/ release/063005_CallCenters.shtml; Press Release, Tex. Health \& Human Servs., New Eligibility System Rolls Out in Travis, Hays Counties (Jan. 24, 2006), available at http://www.highbeam.com/doc/1P3-1025897751.html.

84. TEXAS PLAN, supra note 83, at 1 .

85. See supra notes $79-80$ and accompanying text. 
apply for welfare benefits via the Internet or through call centers rather than face-to-face meetings in welfare offices. Eligibility determinations would be done on a centralized statewide basis rather than in local county offices. Best business practices would be used and this meant that, to the greatest extent possible, the elimination of office visits and face-to-face meetings with government welfare caseworkers. ${ }^{86}$

In October 2005, FSSA issued a Request for Information (RFI), 87 which sought vendors to assist with a state program "to redesign the state's process and systems for determination of client eligibility for public assistance," a system that "should enable Indiana citizens to enroll with a minimum of personal visits." 88 The desired outcome was a "decrease in volume going through local offices." 89 By emphasizing that clients should be able to apply in person, through the Internet, over the phone, by fax, or mail, the RFI also sought to increase the self-sufficiency of applicants for social services. ${ }^{90}$ Presumably, self-sufficiency in this context meant that they did not need anyone's face-to-face assistance to determine whether they were eligible for benefits and if so, which ones and how best to apply for them. Moreover, there was a level of computer savvy assumed that was unrealistic for this population of potential "clients."

86. Int'l Bus. Machs. Corp., No. 49D10-1005-PL-021451, slip op. at 4.

87. The Indiana Department of Administration explains the significance of a request for information as follows:

An agency may choose to research information on a proposed [Request for Proposal] (RFP) without having to commit to doing an RFP by doing a Request for Information (RFI). The RFI is used by agencies to gain information on specifications and pricing for new products, programs or services. The RFI strictly requests information and a contract will not result from the RFI. The RFI is not to be used as a tool to "pre-select" vendors. Responses to the RFI will remain confidential until after the RFP is complete. If no RFP is issued, the RFI responses become public information after the decision is made not to proceed with an RFP.

IND. DEP'T. OF ADMIN., STATE OF INDIANA VENDOR HANDBOOK 8 (2012), available at http://www.in.gov/idoa/files/vendor_handbook.pdf.

88. Int'l Bus. Machs. Corp., No. 49D10-1005-PL-021451, slip op. at 6. The Indiana Department of Administration, acting on behalf of FSSA, followed standard contract procurement procedure by public-private agreement. See generally IND. CoDE $\$$ 5-23-5-1 (2012). In its Request for Proposal it stated explicitly, "[t]his procurement will proceed under IC 5-23, however, we will follow specified sections of IC 5-22 when noted." IND. DeP'T OF ADMIN \& IND. FAMILY \& SOC. SERVS. AdMin., StATE of INDIANA: Request FoR Proposal 6-58: Solicitation FOR Eligibility Determination SERvices 6 (2006), available at http://web.pdx.edu/ pcooper/RFP-6-58.pdf. For an exhaustive discussion of Indiana's procurement process, see generally IND. DEP'T OF ADMIN., supra note 87.

89. Int'l Bus. Machs. Corp., No. 49D10-1005-PL-021451, slip op. at 6 (alterations in original omitted).

90. Id. 
On January 3, 2006, "IBM and a group of [twelve] coalition companies called the 'Hoosier Coalition for Self Sufficiency' submitted a response to the RFI."91 The largest portion of the work among the Coalition members and the largest part of the compensation was to go to Affiliated Computer Services (ACS)-a subsidiary of Xerox-which employed the personnel assisting the processing of eligibility applications. ${ }^{92}$ The state then issued a Request for Proposal and for Best and Final Offer, at which point other participating bidders dropped out, leaving the IBM Coalition as the only potential contract partner. ${ }^{93}$ "Having concluded that the state itself could not modernize its system on its own without the assistance of an independent vendor, on May 11, 2006, [Indiana] announced its intention to award the eligibility modernization contract to the IBM Coalition."94

This approach is what the Family and Social Services Administration recommended in its 2006 report, Eligibility Modernization: The Need for Change. ${ }^{95}$ The FSSA report described to the Governor what he seemed already to have anticipated: "terrible customer service" 96 in the welfare offices that the researchers visited. Citizens in need were "forced" to make more than two million trips a year to various welfare offices around the state. ${ }^{97}$ To remedy this situation, one of the state's requirements for the new system they had in mind was to "reduce the number of mandatory visits to local offices" by "giving clients more avenues to interact with the agency" such as "the Internet, an automated and interactive phone system, and local organizations in the community."98 There was also evidence that such visits were not only inefficient-wasting the time of Indiana citizensbut they led to corruption as well. ${ }^{99}$ On the other hand, less face-to-face time freed up caseworkers to do other things as well. As one state official put it, "[i]t's better for them and cheaper for us if they don't come into the office." 100

91. Id.

92. Id.

93. Id. at 6-7. This is not dissimilar from patterns in other privatized settings where the number of competitors involved is usually smaller than the market theory of competition might suggest. The private prison context is a ready example. See supra note 16.

94. Int'l Bus. Machs. Corp., No. 49D10-1005-PL-021451, slip op. at 7.

95. FSSA REPORT, supra note 73, at 26-28.

96. Int'l Bus. Machs. Corp., No. 49D10-1005-PL-021451, slip op. at 5.

97. Id.

98. FSSA REPORT, supra note 73 , at 5.

99. Indiana v. Int'l Bus. Machs. Corp., No. 49D10-1005-PL-021451, slip op. at 32, 32 n.51 (Marion Super. Ct., Civ. Div. 10 July 18, 2012) (findings of fact, conclusions of law, and judgment for IBM).

100. Int'l Bus. Machs. Corp., No. 49D10-1005-PL-021451, slip op. at 6. 
The question of whether to outsource these modernizing tasks to a private provider was never aired publicly. Whether new technologies could, in effect, be insourced to the government rather than contracted out to the private sector was a question that could have benefitted from public discussion before the decision to outsource was made. Nor was the question of whether these types of reforms were worth pursuing, given the complexity and diverse nature of the makeup of the welfare applicant pool. The question of under what contractual terms the outsourcing project should proceed, however, was subject to additional consideration and public consultation of a sort. Before the contract to outsource welfare eligibility to IBM was signed, the governor appointed an Interagency Review Committee chaired by his own chief of staff and consisting of the heads of six state agencies. ${ }^{101}$ The committee worked for seven months and made further modifications before approving the overall concept and design of the system as outlined in that contract. ${ }^{102}$ The changes were based on the experiences of other states and the committee's analysis of what it thought some of the risks might be. ${ }^{103}$ There were, however, no public hearings on the contract terms ultimately crafted by this committee. The public representative character of this committee consisted of the fact that the members were all a part of the government, appointed by the governor, and serving as heads of their respective administrative agencies. The representation on this committee could have been considerably broader and included actual welfare recipients or their public interest advocates. ${ }^{104} \mathrm{As}$ I shall argue below in part III, a more inclusive process should be institutionalized when future outsourcing occurs, especially when it involves potentially vulnerable populations such as welfare recipients.

As noted above, perhaps the most important goal of the state's reforms was to move away from face-to-face meetings and a fully government-run, caseworker-based system. In addition to being more efficient by lessening trips to a welfare office, the review committee found that " $[t]$ he proposed eligibility system would lessen fraud and abuse by limiting the opportunities a client has to collude with a caseworker because caseworkers would no longer control cases from opening to close."105 Every time a welfare recipient consulted the company involved, they would get a different person responding to their questions. The system had become largely decentralized in that sense.

101. Id at 7 .

102. Id.

103. Id.

104. Cf. id. at 7 (noting the composition of the committee).

105. Id. at 8 (alteration in original) (citation omitted). 
Governor Daniels also directed the Review Committee to ensure that the state employees who were let go and went to work for the selected vendor receive the same or better base salary and comparable benefits to state employees. ${ }^{106}$ This had the effect of reducing the state's workforce and its employee budget as well. ${ }^{107}$ In addition, the committee noted Indiana's policy initiative aimed to promote the development of policies and procedures that underscored the importance of work, accuracy, and caseload integrity across all areas of public assistance and that the governor had "specifically asked the Review Committee to assess whether the path to modernization would help welfare recipients become economically self-sufficient." 108 Presumably, this was an attempt to encourage work whenever possible over the benefits being provided, in accord with the thrust of the 1996 federal act. Another failing of Indiana before this plan was put into effect was that it ranked 50th among the states in the number of welfare recipients that were moved from welfare to work. ${ }^{109}$

The review committee identified several areas of risk in implementing this new system. Modernization of this kind, it noted, had proven to be a significant challenge, as no state had successfully undertaken the task before. ${ }^{110}$ They were aware that both Texas ${ }^{111}$ and

106. Id. Despite the comparable benefits, there is evidence that there were issues related to the change in employment for many former state employees. A report issued by the United States Department of Agriculture noted the following:

Many state employees became ACS employees, which resulted in stressful relationships between individuals who were no longer colleagues. The tension is compounded by different employers being co-located in a single office, each with its own personnel policies (e.g., mandatory overtime and dress code). In addition, many people were fearful that they were going to lose their jobs.

U.S. DEP'T of Agric., FoOd \& NUTRITION SERV., OfFICE of RESEARCh \& ANALysis, Enhancing SuPPlemental Nutrition Assistance Program (SNAP) Certification: SNAP MODERNIZATION EFFORTS: FINAL REPORT 56 (2010), available at http:/www.fns.usda.gov/ora/MENU/Published/snap/FILES/ProgramOperations/Enhanced Certification_Vol2Final.pdf. Indiana state workers do not belong to a union; it was unlikely that that would change as a result of the contract.

107. Indiana state workers are nonunionzed. See Dan Carden, Status of Government Employee Unions Key Difference Between Ilinois, Indiana, NW..COM (Oct. 8, 2011, 9:00 $\mathrm{PM}$, http:/www.nwitimes.com/news/state-and-regional/indiana/article_81a9cd78-ae0e5beb-a141-df4543e2357a.html.

108. Int'l Bus. Machs. Corp., No. 49D10-1005-PL-021451, slip op. at 8.

109. FSSA REPORT, supra note 73 , at 4.

110. Int'l Bus. Machs. Corp., No. 49D10-1005-PL-021451, slip op. at 14. At this time, Texas had only partially implemented its efforts to modernize and privatize its welfare system. See supra note 83. Moreover, Texas had run into problems along the way and ended up terminating its contract with the company that ran these call centers in 2007. See Press Release, Tex. Health \& Human Servs. Comm'n, HHSC, Texas Access Alliance Agree to End Contract Early (Mar. 13, 2007), available at 
Florida ${ }^{112}$ had partially modernized certain segments of state welfare, but on a smaller scale. Modernization in Indiana would require a "brand new work flow and document management system" and "changing the ingrained habits of . . . hundreds of thousands of employees." 113 Still, the Review Committee believed that the status quo was unacceptable and recommended going ahead, noting that "[e]ssential governmental functions and governmental oversight and control will be retained by the state."114

On December 27, 2006, the Governor announced an agreement worth $\$ 1.34$ billion with IBM and ACS to assume control of the programs. ${ }^{115}$ Not only would the companies begin processing claims, they would drastically change the means by which claims were received, analyzed, and approved. The initial press release suggested the scope of the changes involved:

[t]he plan envisions improving delivery of the public safety-net benefits system received by one in six Hoosiers, by making it easier to apply through the

http:/web.archive.org/web/20121031020057/http://www.hhs.state.tx.us/news/release/03130 7_AccessAlliance.shtml.

111. See supra note 83 .

112. Florida currently runs and operates a modernized system called ACCESS Florida; the system runs the administration of food stamps, cash benefits, and Medicaid. See U.S. DEP'T OF AGRIC., FOOD \& NUTRITION SERV., OFFICE OF RESEARCH, NUTRITION \& ANALYSIS, MODERNZATION OF THE FOOD STAMP PROGRAM IN FLORIDA: FINAL REPORT xix (2008), available at http:/www.fns.usda.gov/ora/MENU/Published/snap/FILES/ProgramOperations/ FloridaModern.pdf. ("ACCESS Florida eliminates the old caseworker model of public assistance. Instead of each client having a single caseworker as their point-of-contact, clients may use technology to apply for benefits, and to retrieve and update their case information. When clients do interact directly with DCF staff, such as during eligibility interviews, they are served by the next available worker since the state's technology allows any worker to access all case information."). See also Fla. Dep't of Children \& Families, ACCESS Florida, http://www.myflfamilies.com/service-programs/access-florida-food-medical-assistance-cash (last visited Nov. 2, 2012). Although the state had initially intended to outsource operation of ACCESS Florida to a private firm, the Florida Legislature prohibited that particular effort at privatization. Act effective July 1, 2005, ch. 2005-61, § 6, 2005 Fla. Sess. Law Serv. ch. 2005-61 (West) (repealing 2004 Fla. Laws ch. 2004-267, $\S 114$ ). Thus, ACCESS Florida is a modernized system run entirely by the government. Since 2006, Florida has attempted to privatize its Medicaid program, but has not been successful. See Steve Gara, Florida Medicaid Program in Limbo, EXAMINER.COM (Oct. 8, 2012), http://www.examiner.com/article/florida-medicaidprogram-limbo.

113. Int'l Bus. Machs. Corp., No. 49D10-1005-PL-021451, slip op. at 14 (citation and emphasis omitted).

114. Id. at 9 .

115. See id. at 6, 9. See also Press Release, State of Ind., Governor Signs Contract to Modernize State Eligibility System (Dec. 27, 2006), available at http://www.in.gov/apps/utils/calendar/presscal?PF=aiin\&Clist=196\&Elist=87904. 
Internet and telephone call centers. It also aims to use computers to drive the process with self surveys, instead of time-consuming interviews, to ease case workers' paperwork and reduce error and fraud. ${ }^{116}$

The governor was unequivocal in stating the benefits of the new deal:

For taxpayers, a billion dollars of savings . . . For recipients, better service and a better chance to escape welfare for the world of work and self- reliance. For employees, better compensation and career prospects. For the Indiana economy, 1,000 new quality jobs. No decision we've made is more clearly in the public interest. ${ }^{117}$

The state would save money through the consortium's automated system for welfare claims by reducing the amount of paperwork and reliance on in-person counseling-thereby reducing the requisite manpower. ${ }^{118}$ That said, each of Indiana's ninety-two counties would "retain an office where people could apply in person for benefits, and all final eligibility determinations would be made by state employees."119 Nevertheless, the staff in these offices could now be significantly reduced.

\section{B. The Contract}

The goals of corporate centralization and state based cost-savings were embodied in the contract (Master Services Agreement or MSA) Indiana entered into with IBM, a contract that sought to "transform and modernize the process by which information needed or related to making eligibility determinations is collected, organized, and managed." The overarching policy objectives of the Modernization Project and the Agreement were

(i) to provide efficient, accurate and timely eligibility determinations for individuals and families who qualify

116. Daniels Signs $\$ 1$ Billion Welfare Outsourcing Deal, WTHR.COM (Dec. 27, 2006), http:/www.wthr.com/story/5864292/daniels-signs-1-billion-welfare-outsourcing. deal?clienttype $=$ printable.

117. $I d$.

118. See id.

119. Id. 
for public assistance, (ii) to improve the availability, quality and reliability of the services being provided to Clients by expanding access to such services, decreasing inconvenience and improving response times, among other improvements, (iii) to assist and support Clients through programs that foster personal responsibility, independence and social and economic self-sufficiency, (iv) to assure compliance with all relevant Laws, (v) to assure the protection and integrity of Personal Information gathered in connection with eligibility determination, and (vi) to foster the development of policies and procedures that underscore the importance of accuracy in eligibility determinations, caseload integrity across all areas of public assistance and work and work-related experience for Clients in the Programs. ${ }^{120}$

IBM would determine eligibility for Food Stamps, Medicaid, and Temporary Assistance for Needy Families (TANF). ${ }^{121}$

A memorandum of understanding executed with the MSA also emphasized the importance of economic development activities that were "part consideration" for the MSA.122 The Governor observed that the economic benefits they anticipated were of "enormous importance to the Indiana economy," and his announcement would have been "just as big" if the Project involved those efforts alone. ${ }^{123}$ Indeed, "[o]ut of about 2,200 current FSSA employees [previously] performing the work, about 700 would be retained by the agency. The remaining 1,500 FSSA employees were guaranteed jobs with the IBM group for two years at no less than equal pay and benefits."124 The contract received initial approval from the federal government. The Departments of Health and Human Services and Agriculture conditionally blessed the arrangement, promising to give more money with the successful completion of the first

120. Int'l Bus. Machs. Corp., No. 49D10-1005-PL-021451, slip op. at 10.

121. Id. at 12, 16-17. The Food Stamp program, currently referred to as the Supplemental Nutritional Assistance Program (SNAP), provides food assistance to people and families with little or no income. See supra note 70. TANF is a program that provides cash assistance and supportive services to assist families with children under age eighteen, helping them achieve economic self-sufficiency. See supra note 72. Medicaid is a health insurance program that provides insurance to recipients based on criteria such as income and family size, age, and medical needs. See supra note 71.

122. Int'l Bus. Machs. Corp., No. 49D10-1005-PL-021451, slip op. at 11.

123. Id.

124. Daniels Signs $\$ 1$ Billion Outsourcing Deal, supra note 116. 
stages of the plan. ${ }^{125}$ The first phase of the plan was to be implemented in the state's northern counties and gradually introduced to the others. ${ }^{126}$

The MSA provided that the modernized system would be rolled out in stages. ${ }^{127}$ Initially, IBM would assist in processing social services applications under the existing system. ${ }^{128}$ Next, the modernization system would be implemented on a region-by-region basis. ${ }^{129}$ After this transition period, the project would reach a "steady state" once implemented in all counties. ${ }^{130}$ The MSA established that the state retained all policy-making authority over the project as well as sole authority to make, and sole responsibility for, all eligibility determinations. ${ }^{131}$

The MSA incorporated Key Performance Indicators (KPIs), which if the IBM Coalition failed to meet, would be liable for liquidated damages. ${ }^{132}$ These KPIs required that 99 percent of food stamp cases, Medicaid case actions, Medicaid Disability applications, and TANF case actions be fully processed and transferred to the state no later than three business days prior to the established Federal and State Timelines. ${ }^{133}$ Liquidated damages of $\$ 5,000$ were owed per month in which these KPIs were not met, beginning in September 2008.134 Other KPIs included that call response time should have a mean of 120 seconds or less and hold times for phone calls to the call center should have a mean less than three minutes. ${ }^{135}$

The plan did not receive universal support. There was some political push back from the very start. Then Indiana House Speaker Patrick Bauer claimed that the "Daniels administration was allowing private companies to 'profit from the poor."'136 He and fellow Democrats warned of the possible deprivation of due process rights should regulators lose oversight of the companies.137 Though Speaker Bauer

\footnotetext{
125. See id.

126. See Int'l Bus. Machs. Corp., No. 49D10-1005-PL-021451, slip op. at 15, 20.

127. See id. at 12, 15, 20 (citing MSA $\S 3.2 .1(2)$ ).

128. Id. at 12 (citing MSA $\S 3.1 .3$ ).

129. Id. (citing MSA $\S 3.2 .1(2)$ ).

130. Id. (citing MSA $\S 3.2 .1(1)$ ).

131. Id. at 12-13 (quoting MSA §§ 3.1.1(6)).

132. Id. at $15-17$ (quoting Schedule 10 to the MSA at $\S 4.2 .2$ ).

133. Id. at $16-17$.

134. Id.

135. Id. at 17 .

136. Daniels Signs \$1 Billion Outsourcing Deal, supra note 116.

137. See id. As noted above, Indiana procured its contract with IBM by means of the statutory authority delegated to the Indiana Department of Administration to enter into contractual service agreements. See supra notes 88-93 and accompanying text. The Texas executive branch, on the other hand, worked more directly with the legislature, gaining
} 
promised to hold legislative hearings on the agreement, Governor Daniels nevertheless moved ahead with the contract, suggesting that "he did not need legislative approval to move forward . . . and that many state government services have been outsourced under previous administrations." $138 \mathrm{He}$ was right. The contract procurement process proceeded like any other government contract for services: the Indiana Department of Administration, acting on behalf of FSSA, issued a request for proposal, negotiated with IBM, and eventually carried the procurement process to completion. 139

This was a public-private undertaking. The state, theoretically at least, retained all policy-making authority over the modernization project. And it had a direct operational role in the modernization project itself. It also retained sole authority to make and the sole responsibility for all eligibility determinations, should it decide to use them. ${ }^{140}$ This arrangement was also recognized as experimental in nature and a project with considerable challenges to overcome. The experiences in Texas and Florida were not encouraging and the very nature of the undertaking was extremely difficult. ${ }^{141}$ The programs falling within the project were complex and the processing and approval of applications for benefits for these programs were highly individualized determinations based on unique facts and circumstances. ${ }^{142}$ IBM's performance indicators, however, were pragmatic: ${ }^{143}$ calls answered, speed at which they were dealt with, accuracy of the determinations, and the like. But assumptions were made about the "welfare customers" that really did not fit the characteristics of the population to be served. The digital divide seemed never to come up in the planning or the implementation of this new system. Many if not most welfare recipients were not likely

explicit legislative approval to privatize limited portions of the welfare system in 2003 and explicit approval to proceed with modernization under the watch of a legislative oversight committee in 2007. See supra note 83. Neither Indiana nor Texas proceeded without the delegated authority of the legislature, but in hindsight, Texas did enjoy the benefit of moving forward in an environment of greater political consensus than Indiana.

138. Daniels Signs \$1 Billion Outsourcing Deal, supra note 116.

139. See supra note 88; Int'l Bus. Machs. Corp., No. 49D10-1005-PL-021451, slip op. at 6-7. See also id. at 7 n.13 (noting Governor Daniels' view that a more elaborate version of the "normal procurement decision process" was used here).

140. Int'l Bus. Machs. Corp., No. 49D10-1005-PL-021451, slip op. at 13.

141. Id. at 14. For a discussion of the Texas and Florida modernization efforts and the difficulties experienced in those states, see Mary R. Mannix, Cary LaCheen, Henry A. Freedman \& Marc Cohan, Public Benefits Privatization and Modernization: Recent Developments and Advocacy, CLEARINGHouse Rev., May-June 2008, at 4, 5-12, available at http:/www.nclej.org/documents/PublicBenefitsPrivatizationandModernization-

RecentDevelopmentsandAdvocacy_000.pdf.

142. Int'l Bus. Machs. Corp., No. 49D10-1005-PL-021451, slip op. at 15.

143. Id. 
to be familiar with or even have access to computer technology. And even access to telephones was not always possible depending upon the condition of the applicant. ${ }^{144}$

But quite apart from the access issues involving telephones and computers, the population of potential beneficiaries clearly could benefit from a face-to-face encounter, particularly where benefits might turn on their ability to work or not work. Objective criteria such as age, education, and willingness to work are given their real meaning when a caseworker can see the applicant. Such seemingly objective criteria do not stand up to actually observing an applicant's physical well-being to determine what they can and cannot realistically do. ${ }^{145}$ Issues such as these were raised in the early days of welfare programs and formed the basis of a due process right to a hearing for those about to lose their benefits in the famous case of Goldberg $v$. Kelly. ${ }^{146}$ It may be that there is less need for elaborate adjudicatory proceedings to sort out the issues involved in most cases, but the ability to see the applicant adds enormously to the ability of a caseworker to make the correct decision and provides a modicum of dignity to the applicant, especially if they are ultimately rejected. ${ }^{147}$ Moreover, the applicant is likely to have a number of questions that he or she may not be able to articulate fully without help from the caseworker. Presumably the telephone might be a substitute for such a conversation, but the impersonal nature of the call coupled with the fact that the person on the other end of the line is not likely to be, and specifically is not intended to be, the same person with whom this applicant may have spoken to before. ${ }^{148}$

These limitations-access to computers, timely access to telephones, and the ability to actually see the condition of the applicant-were arguably foreseeable challenges, but no one could have predicted the "perfect storm" that awaited the roll-out of this new approach to welfare. The Great Recession hit in 2008, with the number of claims for assistance growing enormously: benefit applications rose 21 percent and unemployment in

144. See infra notes 173 and accompanying text.

145. See Jerky L. Mashaw, Due Process and the Administrative State 34 (1985); Mashaw, supra note 40, at 1437; William H. Simon, Legality, Bureaucracy, and Class in the Welfare System, 92 YALE L.J. 1198, 1201-19 (1983) (discussing the rise of formalism in welfare administration).

146. 397 U.S. 254 (1970).

147. See id. at 263-65 (balancing the interests of the applicant's due process rights against the government's interest in conserving state resources).

148. See Int l Bus. Machs. Corp., No. 49D10-1005-PL-021451, slip op. at 7-8 ('Rather than be assigned to a single caseworker, clients would be able to contact and work with a variety of people in multiple settings.") (internal quotation marks omitted); Perdue v. Murphy, 915 N.E.2d 498, 501 (Ind. Ct. App. 2009) ("While it is mathematically possible, it is unlikely that a client calling about his or her case would speak to the same employee each time."). 
Indiana skyrocketed to 10.6 percent. ${ }^{149}$ Congress' stimulus plan designed to deal with this downturn increased the amount of benefits to food stamp recipients, which resulted in a huge increase in workload for IBM and its subcontractors. ${ }^{150}$ There were also a number of natural disasters that befell Indiana at that time, including the 2008 floods. ${ }^{151}$ All of this increased the number of applicants asking for benefits that far outstripped what the original contract anticipated. ${ }^{152}$ This is not to say that a purely governmental system would not also have been inundated by the increase in claims, but the enormous increase in demand and the fact it was unanticipated highlights a dilemma involved when a customer service contract model is in play. The government had purchased only a certain amount of service and one of the motivations for outsourcing to private providers was to save money-not spend more. Budget constraints would affect government providers too, but here the mindset could arguably be different. There was a public interest aspect to the crisis that could have justified moving funds for one governmental project to another so as to temporarily, at least, shore up welfare offices that were besieged. Under a contract, however, a product was being sold and that product was, in reality, a certain number of application reviews and decisions. It could not be infinitely expandable. The private provider's profits would be adversely affected if the demands greatly exceeded what the original contract was set up to do. Profits would be lessened if the number of applications far outpaced the numbers of employees hired to deal with these tasks. ${ }^{153}$ In theory, at least, and especially in emergency situations, the state might have more flexibility when it comes to adding additional manpower on a short-term basis than the private sector and the limits of the contracts involved. ${ }^{154}$

\footnotetext{
149. Id. at 22 .

150. See id. at 23.

151. Id. at 23-24.

152. The State and IBM mutually agreed to delay modernization efforts in order to respond to the new work created by the recession and floods. See id. at 25 .

153. This inflexibility and its possible effect on the profit margins of private contractors was also seen in Pennsylvania, which outsourced the management of some of its halfway houses-transitional residences for inmates on parole. The researcher who oversaw a study of the halfway houses' effectiveness on former-inmates' recidivism rates noted that the focus of the halfway houses "had been on filling up beds ... [not] on producing outcomes." Sam Dolnick, Pennsylvania Study Finds Halfway Houses Don't Reduce Recidivism, N.Y. TIMES, Mar. 25, 2013, at A17. In the end, the privately-run halfway house approach did not improve upon the publicly-run approach as far as recidivism was concerned-the rates were the same. PENNSYLVANIA DEPT. OF CORRECTIONS, RECIDIVISM REPORT 33-36 (2013), available at http://www.portal.state.pa.us/portal/server.pt/ document/1324154/2013_pa_doc_recidivism_report_pdf.

154. See Michaels, supra note 51, at 631-40 (discussing the limits of the private sector in providing public services). Professor Jon Michaels argues that corporations are structured to act efficiently in order to maximize profits, which can create incentives to
} 
When the state decided to outsource welfare administration to a consortium of companies, headed by IBM and ACS, these companies were hired, in large part, to modernize the infrastructure used in the processing welfare applications, with special attention given to reducing the need for in-person counseling. The expectation was that human error and corruption would decrease as a result of the move to the automated system. Yet, in October of 2009, only three years into the contract, Governor Daniels surprised many by cancelling the contract with IBM, moving instead to a hybrid system and placing ACS at the helm of the new project. ${ }^{155}$ In the months following, the state and IBM litigated the decision to cancel, the state's ability to seize assets used by the IBM group, and the alleged underperformance by IBM. ${ }^{156}$ These issues are still being litigated today.

\section{Implementation and Cancelation of the Contract}

The IBM group began to assume control over the administration of Indiana welfare claims in 2007. ${ }^{157}$ Despite gradually implementing the program across the state to reduce strain on the new system, it started off poorly even before the floods and economic meltdown occurred. ${ }^{158}$ Both IBM and ACS saw implementation problems from the start. An IBM employee complained that ACS was understaffed, while an ACS employee claimed that there were multiple applications not in queue and duplicate scans of other applications appearing over and over again. ${ }^{159}$ In a 2007 e-mail, FSSA secretary Mitch Roob described persistent problems such as thousands of lost work hours and tens of thousands of unanswered calls. 160

Welfare recipients suffered as a result from these complications during the implementation of this modernization program. The AARP of Indiana complained that, "[t]oo many seniors, people with disabilities

underprovide services. Id, at 631-32. These incentives work at cross-purposes with republican values, which support welfare as a necessity for civic participation. See Michaels, supra note 33, at 1491-95 (2002).

155. See Int'l Bus. Machs. Corp., No. 49D10-1005-PL-021451, slip op. at 36-37; Press Release, State of Ind., State Ends Contract with IBM for Welfare Services (Oct. 15, 2009) [hereinafter State Ends Contract], http://www.in.gov/portal/news_events/43261.htm.

156. See Dave Stafford, State Moves Forward with IBM Appeal, THE INDIANA LAwYER (Aug. 21, 2012), http:/www.theindianalawyer.com/state-moves-forward-with-ibmappeal/PARAMS/article/29507. The case is currently being litigated before the Indiana Court of Appeals under cause number 49A05-1209-462.

157. See Int'l Bus. Machs. Corp., No. 49D10-1005-PL-021451, slip op. at 20.

158. See id. at $20-21$.

159. See id. at 20 .

160. See id. at 20-21. 
and other of our most vulnerable citizens have endured monstrous challenges to address their basic health care, nutritional and other daily necessities."161 In one such instance, an eighty-year-old woman's Medicaid benefits were erroneously cut off. Her benefits were denied because she failed to call into an eligibility hotline on a day because she was hospitalized for congestive heart failure. ${ }^{162}$ She was one of thousands of Indiana residents to have their benefits, such as Medicaid and food stamps, suddenly and erroneously cut off. 163 In 2009, Stacie Kelly was twenty-seven weeks pregnant and did not have health insurance. In order to see a doctor, she applied for Medicaid but did not receive any response for two months despite calling her caseworker and leaving numerous messages. ${ }^{164}$

Brittany Anderson, who suffers from a seizure disorder, was told by FSSA that she would have to reapply for Medicaid benefits in March of 2008.165 When her friend, Melissa Gibson, learned of the potential termination, she called IBM several times to inquire about Brittany's continued receipt of Medicaid benefits and received conflicting responses from IBM representatives and no assistance. When Melissa attempted to reapply for Medicaid benefits on behalf of Brittany, an IBM employee told her that an application for Brittany had already been received and a new one would not be accepted or processed. For the next eight months, whenever Melissa would call to check on the status of her friend's case, she was always told that the case was "pending." Although Brittany and Melissa had signed releases allowing IBM access to Brittany's medical records, IBM never contacted her medical providers. When Brittany was without health coverage, a medical device surgically implanted in her chest failed and she was unable to afford corrective surgery. As a result, her health deteriorated after enduring numerous seizures, and she was eventually forced to withdraw from high school. It was only after Governor Daniels terminated the MSA and Brittany's struggle was featured on local news that the FSSA reinstated her Medicaid benefits. ${ }^{166}$

\footnotetext{
161. Advocates for Seniors, Disabled Take Aim at IBM, THEINDYCHANNEL.COM (Sept. 25, 2009), http:/www.theindychannel.com/news/advocates-for-seniors-disabled-take-aimat-ibm.

162. Matea Gold, Melanie Mason \& Tom Hamburger, Indiana's Bumpy Road to Privatization, L.A. TIMES, (June 24, 2011), available at http://articles.latimes.com/2011/jun/ 24/nation/la-na-indiana-privatize-20110624.

163. Id.

164. Pregnant Woman Frustrated by FSSA Slowness, THEINDYCHANNEL.COM (July 8, 2009), http://www.theindychannel.com/news/pregnant-woman-frustrated-by-fssa-slowness. 165. See Gibson v. Int'l. Bus. Machs. Corp., No. 1:10-cv-00330-LJM-TAB, 2010 WL 3981792 , at ${ }^{\star} 1$ (S.D. Ind. Oct. 8,2010$)$.
}

166. Id. at *2. 
Meanwhile, reports published by the state in 2008 and 2009 regarding the performance of the modernization initiative seemed to indicate nothing but success in terms of the aggregate numbers involved. ${ }^{167}$ In May 2008, Roob reported that "we are serving more people statewide and in a timelier manner than we ever have before."168 In 2009 it was reported that the agency was processing applications for Medicaid, food stamps, and TANF benefits just as quickly as it was before. ${ }^{169}$ Allegations, however, then surfaced that IBM and ACS workers prescreened applicants before state officials could determine whether welfare benefits should have been given. As a 2011 Los Angeles Times article stated, "documents were lost, [and when] cases piled up . . - workers started routinely denying applications just to reduce the backlog." 170 Dozens of cases were filed in court alleging deprivation of due process rights and negligence against the state and IBM. ${ }^{171}$ Many more complained to the FSSA and sought administrative remedies, ${ }^{172}$ only to find litigation the only means of recourse. ${ }^{173}$

167. See Indiana v. Int'1 Bus. Machs. Corp., No. 49D10-1005-PL-021451, slip op. at 2627 (Marion Super. Ct., Civ. Div. 10 July 18, 2012).

168. Id. at 26 .

169. Id.

170. Gold, Mason \& Hamburger, supra note 162.

171. See, e.g., Bowman v. Int'l Bus. Machs. Corp., No. 1:11-cv-0593 RLY-TAB, 2012 WL 5285919 (S.D. Ind. Oct. 23, 2012) (alleging deprivation of due process and negligence); Bowman v. Int'l Bus. Machs. Corp., 853 F. Supp. 2d 766 (S.D. Ind. 2012) (claiming deprivation of due process as Medicaid beneficiaries and bringing a claim for damages under the contract between FSSA and IBM as third-party beneficiaries); Novak v. Ind. Family \& Soc. Servs. Admin., No. 1:10-cv-0677-RLY-DML, 2011 WL 1224813 (S.D. Ind. Mar. 30, 2011) (seeking judicial review for denial of Medicaid benefits and damages for IBM's negligent handling of the application and appeal of denial of Medicaid); Gibson, 2010 WL 3981792.

172. The modernization effort did not alter the right of welfare recipients to appeal a determination for eligibility. IND. CODE $§ 12-15-28-1$ (2012) (right to appeal Medicaid determination); IND. CODE § 12-17.6-8-2 (2012) (right to appeal determination under the Children's Health Insurance Program); IND. CODE $\S 12-10$-17.1-21(3) (2012) (giving authority to the division of aging to adopt appeals procedures); IND. CODE $\S 12-21-5-1.5(7)$ (2012) (giving authority to the division of mental health and addiction to adopt appeals procedures); 470 IND. ADMIN. CODE 10.3-11-1, -2 (2012) (right to appeal determination of eligibility for TANF benefits); 470 IND. ADMIN. CODE 1-4 (2012) (granting the right to request a hearing and appeal before the division of family and children, which is the division responsible for administering, among other programs, food stamps, and TANF benefits). See generally IND. FAMILY \& Soc. SERVS. ADMIN., HEARINGS AND APPEALS: Your RIGHT TO APPEAL UNDER FoOd STAMPS (SNAP), TANF, REFUGEe CASH ASSISTANCE AND MEDICAID/HOOSIER HEALTHWISE, http://www.in.gov/fssa/files/Hearings_and_Appeals_FSSA_1009.pdf (last visited Nov. 7, 2012).

173. See, e.g., Murphy v. Terrell, 938 N.E.2d 823 (Ind. Ct. App. 2010) (class action suit brought against the state alleging deprivation of due process and that the class has a constitutional right to an in-person administrative hearing). See also Perdue v. Murphy, 
FSSA officials suggested that they recognized the problems early in the project, but "yielded to the company's wishes to expand the project" to the remaining counties, thus qualifying for a greater payout from the state. ${ }^{174}$ The expansion left the consortium exposed to the risks of upswings in the number of claims, which is exactly what happened with the 2007 floods and the 2008 financial recession.

Both the state and IBM were proactive in trying to adjust the modernization plan to respond to the problems they encountered. The contract was amended eleven times over the course of the project, which added $\$ 178$ million to the total cost, ${ }^{175}$ and both parties conducted their own extensive assessments of the project.176 Beyond contract amendments, IBM and the state made other adjustments along the way. In November 2008, IBM met with FSSA to propose seventeen systemic changes to adjust to the external problems it was facing, and the state was able to implement many of these reforms. ${ }^{177}$

But in early 2009, after the state began working on these reforms, it sent a letter to the IBM Coalition outlining thirty-six issues that needed to be addressed. ${ }^{178}$ Many of these issues were identical to reforms previously approved at the end of $2008 .{ }^{179}$ Notably, the letter outlined twenty-one issues that were unrelated to existing performance standards under the MSA and six more that were not yet in effect. ${ }^{180}$ At the same time, IBM also did an "end-to-end assessment" which contained several recommendations for improvement, but nonetheless concluded that "any problems on the Project were 'eminently fixable' and that the concept of modernization was sound." 181 In July 2009, the parties agreed on a "Corrective Action Plan," which included both long- and short-term initiatives to address the issues that had been raised in the state's letter and IBM's end-to-end assessment. ${ }^{182}$ The

938 N.E.2d 766 (Ind. Ct. App. 2011), vacated sub nom. Perdue v. Gargano, 964 N.E.2d 825 (Ind. 2012) (class action suit brought against the state alleging deprivation of due process and that the modernized system has a disparate impact on persons with disabilities).

174. Ken Kusmer, Indiana: IBM Welfare Intake Work Flawed from Start, BOSTON.COM (July 21, 2010), http://www.boston.com/business/articles/2010/07/21/indiana_ibm_welfare_ intake_work_flawed_from_start/.

175. Indiana v. Int'l Bus. Machs. Corp., No. 49D10-1005-PL-021451, slip op. at 27 (Marion Super. Ct., Civ. Div. 10 July 18, 2012).

176. See id. at $27,29$.

177. See id. at 28-29.

178. See id. By this time Anne Murphy had replaced Mitch Roob as Secretary of FSSA. Roob had been appointed by Governor Daniels to be the head of the Department of Commerce. Id. at 28.

179. Id. at 29 .

180. Id.

181. Id.

182. See id. 
adjustments seemed to reflect good-faith efforts by both parties to work together to improve the project. But eventually, the state realized that adjustments were not enough; an entirely new approach was needed.

Just two months after signing the Corrective Action Plan, the state decided to move to a modified approach, "Plan B," which abandoned the centralized call center, decentralized eligibility case management, and utilized face-to-face interactions with FSSA staff. ${ }^{183}$ But rather than directly approach IBM about modifying the original plans for complete modernization, the state approached long-time state welfare officials to come up with a different approach. ${ }^{184}$ The main concern was that the original plan had used too much technology, too quickly. ${ }^{185}$ With a new approach in hand, the state then decided to pursue IBM about changing course. ${ }^{186}$ Governor Daniels announced that the decision had nothing to do with the performance of IBM and it appears that the state hoped that IBM would implement the hybrid plan. ${ }^{187}$ IBM initially expressed willingness to move forward with Plan $B$, but eventually concluded that it could not implement the hybrid system without an increase in the contract price that the state could not afford due to budget cuts. ${ }^{188}$

Finally, in October 2009, Governor Daniels, spurred on by increasing pressure from public interest groups, ${ }^{189}$ state Democrats, ${ }^{190}$ and the Federal Department of Agriculture, ${ }^{191}$ canceled the contract with IBM, ${ }^{192}$ despite noting that "[t]he fraud appears to have been stopped and we're still on track to save taxpayers hundreds of millions of dollars" through the new, hybrid system. ${ }^{193}$ The governor conceded

183. Id. at $31-32$.

184. Id. at 33 .

185. See id. Governor Daniels stated, "it is the concept of the system" that is the problem. Id. Furthermore, a state internal e-mail stated the following: "It was a process problem. We just went to technology too fast and will be implementing more face to face to solve the problem." Id. at 33 n. 52 .

186. Id. at 33 .

187. Id.

188. Id. at 34-35.

189. See Mannix, LaCheen, Freedman \& Cohan, supra note 141, at 9-10; Jim Wallihan, Welfare Privatization: Back to the Drawing Board?, 29 THE UNITED SENIOR AdvoCATE, no. 1 , 2010, at 10, available at http://www.usaindiana.org/Advocate\%20\&\%20Briefs/ 10.winterAdvocate.pdf; The Privatization of Indiana's Family and Social Services Agency, Citizens Action Coalition Education Fund, http://cacefindiana.org/node/programs/ health_care/privatization_fssa (last visited Nov. 7, 2012).

190. See Herrell Glad FSSA Recognizes Problems in Privatization, KOKOMOPERSPECTIVE.COM (Aug. 15, 2009, 12:00 AM), http:/kokomoperspective.com/news/ new-herrell-glad-fssa-recognizes-problems-in-privatization/article_5a7353f6-2455-5539b48b-95ca6f69dcaa.html\#user-comment-area.

191. See Mannix, LaCheen, Freedman \& Cohan, supra note 141, at 9.

192. Int'l Bus. Machs. Corp., No. 49D10-1005-PL-021451, slip op. at 36.

193. State Ends Contract, supra note 155. 
that "the intended service improvements have not been delivered, and that's not acceptable."194 In its place, the governor tapped ACS to oversee a hybrid system that would incorporate successful elements of the old welfare system and what is known as the modernized system. ${ }^{195}$ In short, Governor Daniels canceled the contract for a lack of progress made by IBM, and he criticized the program for two primary reasons: "[t]he system tried to remove the burden of required face-to-face meetings and it used a task-based approach rather than a case-based approach to process applications." 196 In addition to removing IBM from the Project, the government seized "more than $\$ 9$ million worth of [IBM's] computers, servers and office furniture" that the company used while in charge. ${ }^{197}$

In response, IBM called the cancelation "unjustified" and added that "[o]ur efforts have significantly improved the Indiana welfare system to the benefit of recipients and all of the state."198 The company noted that it was making sufficient progress-contrary to Governor Daniel's claim-but that "high unemployment led to more demands on the welfare system, making the changes more difficult."199 IBM asserted breach of contract among other claims. It also filed a separate suit against the state, and its claims were consolidated with the state's originally-filed complaint. ${ }^{200}$

In the opening lines of the court opinion, Judge Dreyer of the Marion Superior Court stated that "[n]either party deserves to win this case. This story represents a 'perfect storm' of misguided government policy and overzealous corporate ambition. Overall, both parties are to

194. Id.

195. Int'l Bus. Machs. Corp., No. 49D10-1005-PL-021451, slip op. at 33, 37. Under the MSA, ASC was initially the subcontractor working for IBM. Id. at 30 .

196. State Ends Contract, supra note 155.

197. Kusmer, supra note 174.

198. Indiana Cancels \$1.3 Billion Welfare Privatization Contract, THEINDYCHANNEL.COM (Oct. 20, 2009), http://www.theindychannel.com/news/indianacancels-1-3-billion-welfare-privatization-contract.

199. Ken Kusmer, Ind. Governor Cancels Troubled $\$ 1.3$ Billion Welfare Privatization Contract With IBM, STARTRIBUNE.COM (Oct. 15, 2009), http://www.startribune.com/ templates/Print_This_Story?sid $=64434927$.

200. State v. Int'l Bus. Machs. Corp., 964 N.E.2d 206, 208 (Ind. 2012). In the midst of discovery, the sides produced lists of requested deponents and in-court witnesses; on IBM's list was Governor Mitch Daniels. The state moved to prevent the Governor's testimony, citing Indiana Code section 34-29-2-1-providing the Governor of the state of Indiana is "privileged from arrest on civil process, and from obeying any subpoena to testify." Id. IBM claimed that Daniels's testimony was relevant and central to its claim. The trial court granted IBM's motion, with limitations and the state requested an interlocutory appeal on the issue. Id. at 209. The Indiana Supreme Court agreed to hear the appeal and ultimately ruled that "[t]he privilege afforded by [the] Indiana Code section . . . is absolute" and remanded the case to the trial court. Id. at 209, 212. 
blame and Indiana's taxpayers are left as apparent losers."201 The court found that Indiana had failed to prove that IBM breached its contract, and awarded no damages to the state. The court ordered the state to pay a total of $\$ 52$ million plus interest and fees to IBM, $\$ 40$ million from a previous order, plus a new $\$ 12$ million judgment which predominately covers equipment kept by the state. ${ }^{202}$ Despite these complications and legal woes, Governor Daniels proclaimed that cancelling the contract had been the right action because "now [Indiana] has its most timely, most accurate, most cost effective and fraud free system."203 This, he stated, was always the goal and severing ties with IBM was necessary to achieve it. ${ }^{204}$

\section{LESSONS LEARNED: RE-EMBEDDING MARKET APPROACHES INTO SOCIETY}

At this juncture, we may make several observations about the case just presented. First, Indiana's process of renewing the search for a hybrid approach in some ways confirms the double movement effect predicted by Polanyi, mainly in the disembedding story and its reversal through the political process. ${ }^{205}$ At the same time, Polanyi might not have anticipated that the key actor in the re-embedding process was the Governor, prompted and supported by the legislature. Second, as the limits of a marketized approach became apparent, political pressures to rectify the situation grew, but this did not mean returning to the old regime. Third, re-embedding introduced new requirements-specifically to preserve the conditions' flexibility and innovation associated with the private sector, while also fulfilling the rights of welfare recipients in ways associated with the public sector. I develop these observations further below. What can we learn from this process? Specifically, what role might law play to ensure the optimum conditions of an effective double movement?

201. Indiana v. Int'1 Bus. Machs. Corp., No. 49D10-1005-PL-021451, slip op. at 1 (Marion Super. Ct., Civ. Div. 10 July 18, 2012).

202. Id. at 3.

203. Gov. Mitch Daniels' Response to Ruling in IBM Case, INDYSTAR.COM (July 19, 2012), http://www.indystar.com/article/20120718/NEWS05/207190315/Gov-Mitch-Danielsresponse-ruling-IBM-case.

204. Id.

205. POLANYI, supra note 3 , at 79-80. 


\section{A. Law Reform: Creating Opportunities for Contest and Contestation}

The essence of the double movement is that when the separation of the market from the state goes too far, a politics will develop that demands a return. In this case, we see that alternatives to market approaches emerged when their selective impact on citizens (including costs imposed on them) was deemed unacceptable. ${ }^{206}$ More generally, resistance to marketization through the political process entails both communication and accountability between the state and private citizens. Though vulnerable populations such as welfare recipients are not as likely to push back politically speaking as more privileged groups in society, this makes law reforms designed to re-embed market processes in the state all the more important. At a minimum, law reforms can help ensure that there is a free flow of information about proposed privatization plans and the goals sought to be achieved, as well as an opportunity to comment on these proposals in a timely and meaningful way.

As the Indiana case set forth above shows, such law reforms can help trigger the double movement and channel it effectively-for example, by assuring that innovative market approaches are re-embedded in the state in a way that meets both the substantive goals of the statute and efficiency concerns. Perhaps the most important reform is the realization that the kinds of activities being outsourced in the social services sector are not the same as the building of roads or bridges. Yet the procurement processes employed in this case were those most commonly used for public works projects, with, in this case, an important addition as well. The decision to add a new level of contract review added by the Governor after the bidding process was complete implicitly recognized that this type of contract required greater scrutiny to ensure the state's goals were achieved-it was more complicated than the typical public works or service contract. In the Indiana case, Governor Daniels' decision to appoint a committee of six agency heads to review the contracting process and provisions before signing with IBM was, to some extent, effectively institutionalized by a statute passed in 2007. ${ }^{207}$ Passed as an appropriations rider, the statute requires that large contracts that privatize services traditionally performed by stage agency employees now must be subject to comment by the public and by the state budget committee. ${ }^{208}$ The public hearing must occur at least

206. Id.

207. See Act effective July 1, 2007, 2007 Ind. Legis. Serv. Pub. L. No. 234-2007, § 224 (West) (codified at IND. CoDE § 4-12-13 (2008)).

208. Although Florida has succeeded in modernizing its welfare system, it did so without privatization. See Act effective July 1, 2005, ch. 2005-61, § 6, 2005 Fla. Laws ch. 
thirty days prior entering the agreement. ${ }^{209}$ And although the statute gives the state budget committee the opportunity to make a recommendation concerning the contract thirty days before its enacted, the statute does not require a recommendation. 210 The statute aims more at making the procurement process more transparent rather than creating a substantial hurdle to that process. Moreover, because the opportunity for a public hearing takes place later in the process, there is no opportunity for a public discussion of whether the state should consider privatizing government service in the first place.

There are many reasons why a more elaborate contracting review process is necessary when the duties being outsourced involve welfare. The human dimensions of the product being contracted for are far more complex than the brick and mortar nature of a bridge or a road. Moreover, bidding processes set forth in procurement statutes are concerned primarily with eliminating corruption of a certain kindwhere favoritism is shown to political supporters or the like. ${ }^{211}$ This kind of corruption, as we have seen, was a factor motivating Indiana's welfare reforms, among others, but it is not truly central to the kind of process needed to craft a new welfare benefits delivery system that

2005-61, 6 (repealing Act effective July 1, 2004, ch. 2004-267, § 114, 2004 Fla. Laws ch. 2004-267, 123.) See also Mannix, LaCheen, Freedman \& Cohan, supra note 141, at 10. This is another approach that Indiana could have considered-modernizing the system while refusing to outsource operation and management. The Federal Government has also considered partially foreclosing privatization of welfare services in the food stamp context. In 2007, the House of Representatives enacted a bill that would have mandated that only state employees determine eligibility under the food stamp act and interact with food stamp recipients. See H.R. 2419, 110th Cong. $\$ 4015$ (a)(2)(B) (1st Sess. 2007) ((amending 7 U.S.C. $\S 2020(\mathrm{e})(6))$. However, this mandate did not make it into the final legislation approved by both houses. Food, Conservation, and Energy Act of 2008, Pub. L. No. 110234, §§ 4119-20, 122 Stat. 923 (2008).

209. IND. CODE $\S 4-12-13-2(b)(1)$ (2012). The statute also requires this process if the state wants to have state employees directly provide government services that had formerly been provided by a private vendor-essentially, this changes state policy by moving away from privatized services and reinstating government employees. IND. CODE $\S$ 4-12-13-3(a) (2012). However, the statute allows for an agency director to expedite this process if he or she declares "that an emergency exists that requires the employees of the state agency to directly provide the services that were provided by a private contractor or private vendor." IND. CODE $\S 4-12-13-3(b)$ (2012). Interestingly enough, this emergency provision was passed in 2007 , well before the state terminated its contract with IBM in 2010.

210. IND. CODE $§ 4-12-13-2(b)(2)$.

211. Daniel I. Gordon, Anti-Corruption Internationally: Challenges In Procurement Markets Abroad-Part II: The Path Forward for Using Procurement Law to Help with Development and the Fight Against Corruption, WEST GOVERNMENT CONTRACTS YEAR IN REVIEW CONFERENCE COVERING $2012 \quad 1 \quad$ (2013), available at http://scholarship.law.gwu.edu/cgi/viewcontent.cgi?article=1329\&context=faculty_public ations. 
achieves its substantive goals, including delivering benefits to the needy. To this end, what is essential is the participation of a wide range of stakeholders and citizens, including the most obvious of the stakeholders involved, the welfare applicants themselves.

More importantly, the state itself has interests broader than just lowering the cost of welfare administration when it makes contracts such as these-it also has responsibility for the actual welfare of the applicants involved. The state is the true client in this bargain and it must be sure to write a contract comprehensive enough to ensure these responsibilities are appropriately delegated to the private provider involved so that it can be responsive, not only to taxpayers in general, but to welfare applicants and recipients in particular. The scope of this statutory reform should be expanded. The basic decision to outsource a governmental program is, in and of itself, a significant one and procedural opportunities to question the wisdom of that basic decision should also be provided in a timely way, quite apart from an analysis of the details of the actual outsourcing contract involved. The Indiana statute authorizing a hearing thirty days prior to enactment is a good start at re-embedding markets into the state, but the law should provide for comment much earlier than thirty days before implementation. More specifically, it should enable a discussion of what should be done privately and what should be done in-house before that basic decision becomes a fait accompli.

In addition to holding a public hearing and soliciting a recommendation from the state budget committee, the contract should also be published on a government website ${ }^{212}$ before enactment so that affected stakeholders and their public interest representatives can comment on its specific provisions. ${ }^{213}$ In the Indiana case, there would undoubtedly have been even more significant feedback on the computer literacy of the potential beneficiaries that made up most of the potential welfare recipients, as well as the counter arguments for retaining a substantial face-to-face component of the welfare processes then in place. In fact, the state actually sought such feedback informally while it was implementing its hybrid plan. FSSA issued a press release

212. The Internet did play a major role in the informal response and criticism of the IBM contract. See Mannix, LaCheen, Freedman \& Cohan, supra note 141, at 9-10. Several websites were created that allowed individuals adversely affected by the modernization project to log their complaints and stories. See, e.g., The Privatization of Indiana's Family and Social Services Agency, supra note 189.

213. Governor Daniels, by executive order, already requires that government contracts be posted on the Internet in a searchable database. See Governor of Indiana, Exec. Order No. 05-07 (Jan. 10, 2005); Ind. Dep't of Admin., Executive Document Summary, IN.Gov, http:/www.in.gov/idoa/2525.htm (last visited Nov. 9, 2012) [hereinafter IDOA, Executive Document Summary]. 
seeking comments and recommendations from anyone familiar with the old casework system. ${ }^{214}$ This should now be institutionalized more formally in a notice and comment statutory provision.

Such an expanded contracting approach would produce a better contract that increases participation and feedback for decision makers. The agency involved would have a better and more timely sense of what might work and what might fail. At the same time, knowledge of the contract involved would give potential beneficiaries of these reforms an opportunity to suggest alternative ways of achieving a more efficient system that effectively carries out its substantive goals.

\section{B. Third-Party Beneficiaries}

Quite apart from the processes utilized to create these contracts and the opportunities they provide for various stakeholders, especially potential and actual welfare recipients, to participate, welfare recipients should be treated as third-party beneficiaries of the contract being formulated. What the Indiana case shows in stark relief is that the state was the client in this contract. Further, at least at the outset, access to welfare (and therefore welfare recipients themselves) represented the product for which the state contracted. However, the complexities of this arrangement, including the important differences that existed among the types and needs of the welfare recipients involved, ultimately required more complex processes to determine eligibility, processes that combined new technologies with face-to-face contact as well. It did not make sense to assume certain uniform levels of computer literacy or even access to call centers.

Though welfare applicants and recipients were at times referred to as clients, their rights were represented exclusively by the state. The essence of the Polanyi double movement is that the impetus for re-embedding the state into the market is most likely to come from those most affected-the potential welfare recipients themselves. To this end, providing them with an opportunity for judicial review makes the double movement even more likely to occur. Contracts between private companies and states could recognize welfare recipients as third-party beneficiaries to the contract to allow recipients legal redress

214. Press Release, Ind. Family \& Soc. Servs. Admin., FSSA Seeks Input on Hybrid System (Nov. 5, 2009), available at http:/www.in.gov/activecalendar/ EventList.aspx?fromdate $=11 / 5 / 2009 \&$ todate $=11 / 5 / 2009 \&$ display=Day\&type=public\&event idn=7191\&view=EventDetails\&information_id=14399. 
when private contractors violate the terms of the contract in a way that results in the unlawful deprivation of benefits. ${ }^{215}$

Indiana law recognizes third-party beneficiaries when (1) the parties to the contract intend to benefit a third party, (2) the contract imposes a duty on one of the parties in favor of the third party, and (3) the performance of the terms of the contract directly benefits the third party. ${ }^{216}$ However, courts will not interpret a contract so as to render any clauses, phrases, or words in a contract meaningless. Therefore, contracts that include "no third-beneficiary clauses" unambiguously state the parties' intent to not create third-party beneficiaries. ${ }^{217}$ The MSA discussed above had such a clause. ${ }^{218}$ The Indiana legislature could therefore enact legislation that would make the state's agreement to such a clause in a contract with vendors for the privatization of government services a violation of public policy. Moreover, the legislature could also require language in the contract explicitly making welfare recipients third-party beneficiaries.

It is ironic that the only party that was able to challenge IBM's performance was the state. Given the diverse interests at stake and the state's desire to have its contract work as efficiently as possible, it might not be as willing to challenge the contractor as those whose benefits are very much on the line. At a minimum, making the proposed contract more available publicly before it is signed would enable potential welfare recipients to determine whether a third-party beneficiary clause in fact exists in the contract, giving them the chance to advocate for this means of holding IBM accountable to its promises.

215. Welfare recipients would enjoy third-party beneficiary status alongside their existing rights to appeal welfare determinations under existing law. See supra note 173.

216. Bowman v. Int'l Bus. Machs. Corp., 853 F. Supp. 2d 766, 769 (S.D. Ind. 2012). The relevant language in the contract stated:

No Third-Party Beneficiaries. Other than the indemnity rights under Article 17, (I) nothing contained in this Agreement is intended or shall be construed to confer upon any person or entity (other than the Parties hereto) any rights, benefits or remedies of any kind or character whatsoever, and (ii) no person or entity shall be deemed a third-party beneficiary under or by reason of this Agreement.

Id. at 769-70 (emphasis omitted) (citing MSA § 21.6).

217. In Bowman, the Southern District of Indiana determined that welfare recipients (specifically, Medicaid recipients) were not third-party beneficiaries to the MSA in order to avoid rendering the "No Third-Party Beneficiaries" clause ineffective or meaningless. Id. at 771-72.

218. See id. at $769-70$. 


\section{Information}

Additional regulation involving potential contractors in social services contracts of this sort should also be considered. ${ }^{219}$ In general, the records of private corporations are not subject to the Freedom of Information Act (FOIA). ${ }^{220}$ Likewise, in Indiana, private corporations that provide a fee-for-service for the state are not subject to the Indiana Access to Public Records Act (APRA). ${ }^{221}$ However, states such as Alabama, Arizona, Hawaii, and Vermont, have started initiatives to promote corporate transparency by requiring contractors to disclose all subcontractors which they will directly contract with on each project, and to require that the information be posted on the Internet. ${ }^{222}$ Other states, like Connecticut, go further and require that all contractors performing a government function normally performed by a state agency ensure that that state agency receive all copies of documents related to the performance of that government function and that all documents be subject to disclosure under FOIA. ${ }^{223}$ In other words, disclosure is now inextricably linked to the performance of a government function. ${ }^{224}$

219. Cf. Ellen Dannin, Red Tape or Accountability: Privatization, Public-ization, and Public Values, 15 CoRNELl J.L. \& PUB. POL'Y 111, 113 (2005) ("Today, it is easier to see that arguments for or against privatization are actually about accountability.").

220. See U.S. Dept. of Justice v. Tax Analysts, 492 U.S. 136 (1989) (holding that an "agency record" under the FOIA must first, be created or obtained by the agency, and second, must be under the control of the agency at the time the FOLA request was made).

221. IND. CODE § 5-14-3-2.1 (2012). Indiana's version of the Freedom of Information Act, the APRA can be found at $\S 5-14-3-1$ through -10 (2012). The statute defines "public record" as:

any writing, paper, report, study, map, photograph, book, card, tape recording, or other material that is created, received, retained, maintained, or filed by or with a public agency and which is generated on paper, paper substitutes, photographic media, chemically based media, magnetic or machine readable media, electronically stored data, or any other material, regardless of form or characteristics.

§ 5-14-3-2(n). See generally Eric J. Graninger, Indiana Opens Public Records: But (b)(6) May Be the Exemption That Swallows the Rule, 17 IND. L. REV. 555 (1984).

222. See S.B. 36, 2010 Reg. Sess. (Ala. 2010), available at

http://alisondb.legislature.state.al.us/acas/searchableinstruments/2010rs/bills/sb36.htm; H.B. 2325, 49th Leg., 2d Reg. Sess. (Ariz. 2010), available at http:/www.azleg.gov/ legtext/49leg/2r/bills/hb2325p.pdf; S.B. 2868, 25th Leg., Reg. Sess. (Haw. 2010), available at http://www.capitol.hawaii.gov/session2010/bills/SB2868_.pdf; H.R. 748, 2009-2010 Leg. Sess. (Vt. 2010), available at http://www.leg.state.vt.us/docs/2010/bills/Intro/H-748.pdf.

223. See Act of July 6, 2001, § 2, 2001 Conn. Acts. 01-169 (Reg. Sess.). See generally Greg Bass \& Harry Hammitt, Freedom of Information Act Access to Documents of Private Contractors Doing the Public's Business, 35 CleARINGHouse REV. 607 (2002).

224. Bass \& Hammitt, supra note 223, at 612 . 
Shortly after he was elected in 2004, Governor Daniels issued an executive order requiring that the Department of Administration log and summarize, on the Internet, "the significant terms and conditions and other key elements of all written contracts to which the State becomes a party." 225 This online index is searchable and free of charge to the public. ${ }^{226}$ This index does not include agreements between government contractors and subcontractors, and the Indiana APRA ${ }^{227}$ does not explicitly mandate public disclosure of subcontracts. But it does not explicitly exempt them either. 228 Moreover, in the MSA between IBM and the state, the parties agreed that all information in the possession of the state was subject to an APRA request unless the contractor had formally designated the information "confidential." 229 The fact that the state negotiated this kind of language suggests that it understands the APRA to mean that agreements between contractors and subcontractors in possession of the state would be subject to an APRA request as long as the vendor did not formally designate them as "confidential."230 Indiana could, nevertheless, be more explicit about the right of welfare recipients and other interested parties to request information from the state concerning privatization efforts.

\section{CONCLUSION}

Polanyi's analysis of double movement is useful for considering the limits of the market in relation to specific substantive programs. In the welfare case study presented above, the government ultimately remained in control of the programs involved, but it sought to substitute private providers where it had formerly administered programs through a diverse concatenation of state and county offices. In the context of welfare, then, states became clients as new best business practices substituted for traditional government case work. In Polanyi's terms we can assess the extent to which marketization of the administration of welfare disembeds the market from the state only to return key services

225. Governor of Indiana, Exec. Order No. 05-07 (Jan. 10, 2005).

226. Id. See IDOA, Executive Document Summary, supra note 213.

227. See IND. CoDE § 5-14-3-1 to -10 (2012).

228. See id.

229. See MSA § 9.11.1, .2 (on file with the author).

230. Moreover, in the transportation context, the Indiana Department of Transportation (INDOT) prohibits general contractors from subcontracting work in excess of $\$ 100,000$ without its approval. The agency has to subject the subcontractor to a prequalification process, which involves certain required disclosures to the agency. See 105 IND. ADMIN. CODE 11-2-10 (2012). The information submitted to the agency prior to approval would likely be exempt from the ARPA under the state's deliberative process privilege, see IND. CODE $§ 5 \cdot 14-3-4(b)(6)(2012)$, but the final contract would probably be publicly available. 
to the state after a perceived failure of the contract on the part of the private provider. The example suggests we may look forward to new relationships between public and private entities that in turn suggest new uses of law and the need for new law reforms.

Understanding how different conceptions of globalization yield different approaches to providing for and conceptualizing social services-analyzing, in other words, some of the domestic faces of globalization-gives us a chance to think practically and conceptually about the law's role, especially if law is to be a means by which we can rethink the relationship of economy and society for vulnerable populations. Indiana's efforts to modernize welfare were initially consistent with an ideological version of neoliberalism that relied heavily on markets as substitutes for traditional governmental provision of services. Yet the double movement predicted by Polanyi occurred. The political process pushed back and the complaints of many potential and actual welfare recipients ultimately seemed to register. Faced with challenges, the strict binary choice between government and the market inherent in that ideology gave way to a more hybrid (and more realistic) approach-a new mix of market streamlining and face-to-face encounters with welfare recipients. New relationships between private providers of services, the government and the potential beneficiaries of this public-private partnership, were formed, even as the limits of the marketization of welfare administration in Indiana were reached. Those limits included a misreading of the needs of welfare recipients as if they were like any set of potential customers. The new system that emerged out of the lawsuit leaves more room for judgment and discretion. A binary approach (dividing best business practices from government) simply could not provide the basis for resolving the toughest issues. Indeed, when the numbers of welfare claims rose dramatically due to floods and an economic crisis, IBM could not simply add more people to its payroll and efficiently absorb all of these new costs. There were limits to what a for-profit corporation was able to do to carry out a contract at a certain cost. ${ }^{231}$ Its stockholders implicitly imposed those limits. After the contract dispute and the breach of contract suit, a hybrid approach emerged-hybrid, not only in the methodology for assessing eligibility claims, but hybrid also in the sense that it was now recognized that private corporate efficiency alone

231. See supra text accompanying note 175 (noting the fact that changes to the MSA resulted in $\$ 178$ million in additional cost for the state). 
could not absorb the additional costs of the economic and natural crises that took place. ${ }^{232}$

When market approaches are proposed for the administration of social services and applied to vulnerable populations that by definition usually lack significant political power, law should provide the means for keeping markets connected to the state. Allowing for greater public participation in the contracting process and providing the information necessary to make such participation effective would be an important reform. As Polanyi argued, there has never been a self-regulating market, but this does not mean the idea of self-regulation is unimportant or without high stakes. ${ }^{233}$ Law is necessary not only to ensure that property rights exist and contracts are enforced, but it is also necessary to connect the market and the state in ways that increase efficiency without undermining what should be the main goal of any welfare program: the actual welfare of the people it is meant to serve.

232. See supra text accompanying note 214 (noting the fact that IBM was ultimately unable to implement the "Plan B" hybrid approach because the state could not afford to pay the additional costs that such a switch would require).

233. See Joseph E. Stiglitz, Foreword to POLANYI, supra note 3, at xiii. 